\title{
Targeted Review: Medications for Acute Migraine Treatment
}

\author{
Irene Worthington ${ }^{1}$, Tamara Pringsheim ${ }^{3}$, Marek J. Gawel ${ }^{1,8,9}$, \\ Jonathan Gladstone ${ }^{1,2}$, Paul Cooper ${ }^{4}$, Esma Dilli ${ }^{5}$, Michel Aube ${ }^{6}$, \\ Elizabeth Leroux ${ }^{7}$, Werner J. Becker ${ }^{3}$ on behalf of the Canadian Headache \\ Society Acute Migraine Treatment Guideline Development Group
}

\begin{abstract}
Objective: To assess the evidence base for drugs used for acute treatment of episodic migraine (headache on $\leq 14$ days a month) in Canada. Methods: A detailed search strategy was employed to find relevant published clinical trials of drugs used in Canada for the acute treatment of migraine in adults. Primarily meta-analyses and systematic reviews were included. Where these were not available for a drug or were out of date, individual clinical trial reports were utilized. Only double-blind randomized clinical trials with placebo or active drug controls were included in the analysis. Recommendations and levels of evidence were graded according to the principles of the Grading of Recommendations Assessment, Development and Evaluation (GRADE) Working Group, using a consensus group. Results: Eighteen acute migraine medications and two adjunctive medications were evaluated. Twelve acute medications received a strong recommendation with supporting high quality evidence for use in acute migraine therapy (almotriptan, eletriptan, frovatriptan, naratriptan, rizatriptan, sumatriptan, zolmitriptan, ASA, ibuprofen, naproxen sodium, diclofenac potassium, and acetaminophen). Four acute medications received a weak recommendation for use with low or moderate quality evidence (dihydroergotamine, ergotamine, codeine-containing combination analgesics, and tramadol-containing combination analgesics). Three of these medications were NOT recommended for routine use (ergotamine, and codeine- and tramadol-containing medications), and strong recommendations were made to avoid use of butorphanol and butalbital-containing medications. Both metoclopramide and domperidone received a strong recommendation for use with acute migraine attack medications where necessary. Conclusion: Our targeted review formulated recommendations for the available acute medications for migraine treatment according to the GRADE method. This should be helpful for practitioners who prescribe medications for acute migraine treatment.
\end{abstract}

RÉSUMÉ: Revue ciblée : les médicaments pour traiter la crise aiguë de migraine. Objectif : Le but de l'étude était d'évaluer les données sur lesquelles est fondée l'utilisation des médicaments pour le traitement de la crise aiguë de migraine épisodique (céphalée présente $\leq 14$ jours par mois) au Canada. Méthode : Nous avons utilisé une stratégie de recherche détaillée pour identifier les essais cliniques publiés qui étaient pertinents et qui portaient sur les médicaments utilisés au Canada pour le traitement de la crise aiguë de migraine chez l'adulte. Ce sont principalement des méta-analyses et des revues systématiques qui ont été utilisées. Seuls les essais cliniques randomisés à double insu, contrôlés par placebo ou médicament actif, ont été inclus dans l'analyse. Les recommandations et les niveaux de preuve ont été classés selon les principes du Grading of Recommendations Assessment, Development and Evaluation (GRADE) Working Group, par un groupe de consensus. Résultats : Dix-huit médicaments pour traiter la crise aiguë de migraine et deux médicaments d'appoint ont été évalués. Douze médicaments ont reçu une forte recommandation fondée sur des données de haute qualité pour leur utilisation dans le traitement de la crise aiguë de migraine (l'almotriptan, l'élétriptan, le frovatriptan, le naratriptan, le rizatriptan, le sumatriptan, le zolmigriptan, l'ASA, l'ibuprofène, le naproxène sodique, le diclofénac potassique et l'acétaminophène). Quatre médicaments pour traiter la crise aiguë de migraine ont reçu une recommandation faible fondée sur des données de qualité faible ou modérée (la dihydroergotamine, l'ergotamine, les analgésiques contenant de la codéine et les analgésiques contenant du tramadol). Trois de ces médicaments n'étaient pas recommandés pour utilisation de routine (l'ergotamine et les médicaments contenant de la codéine et les médicaments contenant du tramadol) et des recommandations fortes ont été émises contre l'utilisation de médicaments contenant du butorphanol et du batalbital. Le métoclopramide et le dompéridone ont reçu une forte recommandation pour leur utilisation en association avec les médicaments pour traiter les crises aiguës de migraine si nécessaire. Conclusion : Notre revue ciblée nous a mené a formuler des recommandations selon la méthode GRADE concernant les médicaments disponibles pour traiter la crise aiguë de migraine. Ceci devrait aider les médecins qui prescrivent des médicaments pour traiter la crise aiguë de migraine.

Can J Neurol Sci. 2013; 40: Suppl. 3 - S10-S32

Canadian guidelines for the pharmacological treatment of migraine were first published in $1997 .{ }^{1}$ At that time, the only migraine specific medications available were the ergot derivatives (ergotamine and dihydroergotamine), and the $5-\mathrm{HT}_{1 \mathrm{~B} / 1 \mathrm{D}}$ receptor agonist (triptan), sumatriptan. Since publication of these guidelines, another six triptans have become available in Canada. Non-specific acute medications (e.g., ASA, NSAIDs, and acetaminophen) also have a role in migraine
From ${ }^{1}$ Sunnybrook Health Sciences Centre, Toronto, Ontario; ${ }^{2}$ Gladstone Headache Clinic, Toronto, Ontario; ${ }^{3}$ University of Calgary and the Hotchkiss Brain Institute, Calgary, Alberta; ${ }^{4}$ University of Western Ontario, London, Ontario; ${ }^{5}$ University of British Columbia, Vancouver, British Columbia; ${ }^{6} \mathrm{McGill}$ University, Montreal,

Quebec, ${ }^{7}$ University of Montreal, Montreal, Quebec; ${ }^{8}$ Rouge Valley Health System Centenary, Toronto, Ontario; ${ }^{9}$ Women's College Hospital, Toronto, Ontario, Canada. Received June 9, 2013. Final Revisions Submitted June 26, 2013.

Correspondence to: W.J. Becker, Division of Neurology, 12th Floor, Foothills Hospital, 1403 29th St NW, Calgary, Alberta, T2N 2T9, Canada. 
management. The objective of this section of the guideline is to assess the evidence base for drugs used for acute treatment of episodic migraine (headache on $\leq 14$ days a month) in Canada.

\section{METHODOLOGY}

A targeted review of the literature as outlined below was completed to assess available evidence for acute migraine medications in adults. Only drugs available in Canada are included in the guideline. Appendix 1 provides more information on the development of this guideline. For further details on the general principles of acute medication use, please see Section 1 of this guideline. Section 3 provides treatment strategies for choosing a specific acute medication for an individual patient.

\section{Literature Search Strategy}

A MEDLINE search of the English language for migraine disorders and use of triptans, ergotamine, dihydroergotamine, analgesics, NSAIDs, and antiemetics was performed. Only randomized, controlled trials (RCTs) and meta-analyses/ systematic reviews of acute migraine medications in adults (18 years-of-age and older) and available in Canada were included. The initial search was limited to the years 1996 - May 2006 (first Canadian migraine guidelines were published in 1997). The search was updated in May 2010, and again in May 2012.

The following terms were used:

- exp. migraine disorders, and

- sumatriptan or almotriptan or eletriptan or naratriptan or

rizatriptan or zolmitriptan or frovatriptan or "triptan", or

- exp. anti-inflammatory agents, non-steroidal, or

- exp. aspirin, or acetaminophen, or exp. analgesics, or

- ergotamine or dihydroergotamine, or

- exp. barbiturates or butalbital, or

- metoclopramide or domperidone or dimenhydrinate or

exp. antiemetics

- limits: human, adults (18 years-of-age and older), English, randomized controlled trial (RCT) or metaanalysis

The Cochrane Collaboration ${ }^{\circledR}$ and EMBASE were also searched for systematic reviews/meta-analyses. Clinical trials of acute medications used in the emergency room (e.g., parenteral antiemetics) were excluded.

\section{Evaluating Efficacy of Acute Therapies (endpoints)}

Various endpoints to assess efficacy of acute therapies have been used in clinical trials. Primary endpoints include "headache response" and "pain-free". "Headache response" (also called "pain relief" or "headache relief") is defined as a decrease in headache intensity from moderate or severe to mild or none, evaluated at pre-specified time intervals (e.g., 1, 2 or 4 hours). This endpoint has been used in most clinical trials. A "pain-free" outcome (moderate or severe to none) can also be measured at pre-specified time intervals. This is a desirable endpoint, which is endorsed by the International Headache Society (IHS); however, many older trials did not use this endpoint. "Sustained pain-free" refers to the number $(\%)$ of patients who are pain-free at two hours, and remain pain-free over the next 22 hours (without additional acute medication). Headache recurrence refers to the re-emergence of a moderate or severe headache (generally within 24 hours) after an initial headache response.

Consistency of response refers to reproducible pain relief over several attacks. Other secondary outcomes include the ability to reduce associated symptoms of nausea, vomiting, photophobia and phonophobia. Reduction in clinical disability refers to the medication's ability to reduce functional impairment due to pain and associated migraine symptoms. These outcomes may be measured within a single attack or across multiple attacks. The most important outcomes desired by patients are pain-free outcomes (two hour pain-free) and sustained pain-free over 24 hours. $^{2}$

Comparison of acute migraine therapies is complicated by use of different outcome measures in different clinical trials. Debate continues about the best outcome measure in assessing a drug's efficacy in acute migraine therapy. It should be noted that newer drugs (e.g., triptans) tend to have more RCTs and better trial methodology than older drugs (e.g., ergot derivatives); this may result in newer drugs being favoured over older ones.

\section{Criteria for Considering Studies for this Guideline}

Only RCTs and meta-analyses/systematic reviews of acute migraine medications in adults (English language) were included in this guideline. Due to the large number of placebo-controlled trials of individual triptans, meta-analyses/systematic reviews, if available, rather than individual RCTs were included. However, if no meta-analyses/systematic reviews were found for a particular drug, then RCTs were included. Clinical trials of acute medications in the emergency room setting or in pediatric patients were excluded.

\section{Methods of the Review}

Titles and abstracts of studies and meta-analyses identified by the literature search were screened for eligibility by two independent reviewers for the initial search (IW and MJG), for the second search (up to May 2010; IW and TP), and for the third search (2010 - May 2012; IW and WJB). Papers that could not be excluded with certainty on the basis of the information contained in the title or abstract were reviewed in full. Papers passing the initial screening process were retrieved and the full text was reviewed.

\section{Grading of Recommendations and Assessment of Overall Quality of Evidence}

The recommendations were graded based on the principles of the Grading of Recommendations Assessment, Development and Evaluation (GRADE) Working Group. Using the GRADE system, the strength of a recommendation reflects the extent to which we can be confident that the desirable effects of an intervention outweigh the undesirable effects. ${ }^{3}$ The strength of a recommendation in the GRADE system is based on several factors including 4 :

1. The balance between the desirable and undesirable consequences of a therapy, for example, the balance between the benefits and the side effects of a drug.

2. The quality of the evidence on which judgements of the magnitude of the benefit and the potential harm of an intervention are based. 
Table 1: Levels of evidence: GRADE system³

\begin{tabular}{l|l}
\hline $\begin{array}{l}\text { Level of } \\
\text { Evidence }\end{array}$ & \multicolumn{1}{c}{ Definition } \\
\hline High quality & $\begin{array}{l}\text { We are confident that the true effect lies close } \\
\text { to the estimate given by the evidence available. }\end{array}$ \\
\hline Moderate quality & $\begin{array}{l}\text { We are moderately confident in the effect } \\
\text { estimate, but there is a possibility it is } \\
\text { substantially different. }\end{array}$ \\
\hline Low quality & $\begin{array}{l}\text { Our confidence in the effect estimate is limited. } \\
\text { The true effect may be substantially different. }\end{array}$ \\
\hline Very low quality & We have little confidence in the effect estimate. \\
\hline
\end{tabular}

We graded the strength of the recommendations in this section of the guideline based on the above, using expert consensus groups (see Appendix 1). Uncertainty about or variability in patient values and preferences, also part of the GRADE process, were considered. We did not specifically consider treatment cost. The quality of evidence for or against the use of a drug was placed into one of four categories: high, moderate, low, and very low. ${ }^{5}$ Importantly, these categories were used to classify the body of evidence related to a medication rather than individual research studies or clinical trials. Definitions for the categories used for evidence quality are given in Table 1.

The GRADE system was chosen to classify the recommendations in this guideline because it appeared to allow for the best characterization of a recommendation, given that drug efficacy, drug side effects, and the degree of evidence available in the literature were all considered in grading a recommendation. There is some evidence that it is among the best recommendation grading system in terms of influencing the decisions of clinicians. ${ }^{6}$
GRADE recommendations are made in two categories. A strong recommendation means that the intervention could be used for most patients, and that the benefits of therapy outweigh the potential risks. A weak recommendation indicates that the intervention could still be applied to a majority of patients, but it would not be appropriate for many. With a weak recommendation, the balance between risks and benefits is closer or more uncertain. In other words, whether the intervention is suitable for a patient depends a great deal on the clinical situation and the nature of the patient. For this reason, weak recommendations are sometimes called "conditional" recommendations, as whether they are appropriate depends (or is conditional) on the details of the clinical situation much more so than for a strong recommendation..$^{7}$ The quality of evidence supporting the recommendation indicates how much confidence we have in that recommendation. The meaning of the various recommendation categories and their clinical implications are given in Table 2.4,5,7 As shown in Table 2, it is important to recognize that the recommendations as formulated in GRADE are somewhat dichotomous. If the benefits clearly outweigh the risks and burdens, a medication gets a strong recommendation, even though the evidence that the drug is effective may not be strong. Thus, for a drug with very few side effects, it is possible to have a strong recommendation coupled with low quality evidence (i.e., "Strong - low quality evidence").

\section{ACUTE THERAPIES: EVIDENCE FOR EFFICACY}

\section{Migraine-Specific and Non-Specific Agents}

In 2002, a quantitative systematic review/meta-analysis (54 trials) of pharmacological treatments (triptans, dihydroergotamine, ASA plus metoclopramide) for acute migraine concluded that most interventions are effective. However, this review did not include NSAIDs or acetaminophen. Numbers-needed-to treat (NNTs) were calculated. For headache relief at 2 hours (h), NNTs ranged from 2.0 for subcutaneous

Table 2: Recommendation grades: meaning and clinical implications*

\begin{tabular}{|c|c|c|}
\hline Recommendation Grade & Benefit versus Risks & Clinical Implications \\
\hline Strong - high quality evidence & $\begin{array}{l}\text { Benefits clearly outweigh risks and } \\
\text { burden for most patients }\end{array}$ & $\begin{array}{l}\text { Can apply to most patients in most } \\
\text { circumstances }\end{array}$ \\
\hline $\begin{array}{l}\text { Strong - moderate quality } \\
\text { evidence }\end{array}$ & $\begin{array}{l}\text { Benefits clearly outweigh risks and } \\
\text { burden for most patients }\end{array}$ & $\begin{array}{l}\text { Can apply to most patients, but there is a } \\
\text { chance the recommendations may } \\
\text { change with more research }\end{array}$ \\
\hline Strong - low quality evidence & $\begin{array}{l}\text { Benefits clearly outweigh risks and } \\
\text { burden for most patients }\end{array}$ & $\begin{array}{l}\text { Can apply to most patients, but there is a } \\
\text { good chance the recommendations could } \\
\text { change with more research }\end{array}$ \\
\hline Weak - high quality evidence & $\begin{array}{l}\text { Benefits are more closely balanced } \\
\text { with risks and burdens for many } \\
\text { patients }\end{array}$ & $\begin{array}{l}\text { Whether a medication is used will } \\
\text { depend upon patient circumstances }\end{array}$ \\
\hline Weak - moderate quality evidence & $\begin{array}{l}\text { Benefits are more closely balanced } \\
\text { with risks and burdens for many } \\
\text { patients }\end{array}$ & $\begin{array}{l}\text { Whether a medication is used will } \\
\text { depend upon patient circumstances, but } \\
\text { there is less certainty about when it } \\
\text { should be used }\end{array}$ \\
\hline Weak - low quality evidence & $\begin{array}{l}\text { Benefits are more closely balanced } \\
\text { with risks and burdens }\end{array}$ & $\begin{array}{l}\text { There is considerable uncertainty about } \\
\text { when to use this medication }\end{array}$ \\
\hline
\end{tabular}

*Only categories used in this guideline are shown 
sumatriptan $6 \mathrm{mg}$ (most effective) to 5.4 for naratriptan $2.5 \mathrm{mg}$ (least effective). For pain-free endpoint at $2 \mathrm{~h}$, NNTs ranged from 2.0 for subcutaneous sumatriptan $6 \mathrm{mg}$ (most effective) to 8.6 for ASA $900 \mathrm{mg}$ plus metoclopramide $10 \mathrm{mg}$ (least effective). For sustained relief endpoint over 24 hours (headache response at $2 \mathrm{~h}$ and no recurrence within $24 \mathrm{~h}$ ), NNTs ranged from 2.8 for eletriptan $80 \mathrm{mg}$ (most effective; not an approved dose in Canada) to 8.3 for rizatriptan $5 \mathrm{mg}$ (least effective). ${ }^{8}$

\section{MIGRAINE-SPECIFIC AGENTS}

\section{Triptans (selective serotonin $5-\mathrm{HT}_{1 \mathrm{~B} / 1 \mathrm{D}}$ receptor agonists) Overview}

The triptans are serotonin (5HT) agonists that are relatively specific for the $5 \mathrm{HT}_{1 \mathrm{~B}}$ and $5 \mathrm{HT}_{1 \mathrm{D}}$ receptors. Because of this specificity, they offer relatively good migraine relief for many patients, with fewer side effects than the older ergot derivatives. There are currently seven triptans available in Canada: almotriptan (oral tablet), eletriptan (oral tablet), frovatriptan (oral tablet), naratriptan (oral tablet), rizatriptan (oral tablet, orally disintegrating tablet), sumatriptan (subcutaneous injection, oral tablet, fast-disintegrating oral tablet, nasal spray), and zolmitriptan (oral tablet, orally disintegrating tablet, nasal spray). Triptans are vasoconstrictors and therefore, are contraindicated in patients with coronary and cerebrovascular disease, but have proven remarkably safe in patients without vascular disease..$^{9-11}$ There has also been concern about serotonin syndrome, particularly when the triptans are used in association with other drugs that enhance serotonergic activity, but clinical experience indicates that serotonin syndrome must be extremely rare with triptan use, even in the presence of concomitant selective serotonin reuptake inhibitor (SSRI) use. ${ }^{12,13}$ Section 3 of the guideline discusses all these issues in more detail. A disadvantage of triptans is their relatively high cost compared to other acute therapies; however, generic versions of triptans are now available at a slightly lower cost.

There is no single, randomized, controlled trial comparing all of the triptans with each other. Most trials compare a triptan to placebo, and head-to-head trials usually compare sumatriptan with one other triptan. Therefore, meta-analyses and comprehensive reviews (e.g., Cochrane Database) must be used to compare efficacy among triptans. ${ }^{9}$

\section{Meta-analyses/systematic reviews of triptans}

A meta-analysis of 53 randomized, double-blind, controlled (placebo or active comparator) trials in adults published in 2002 concluded that all oral triptans are effective and well tolerated. ${ }^{14}$ This meta-analysis included published studies, as well as "raw patient data" provided by pharmaceutical companies. Rizatriptan $10 \mathrm{mg}$, eletriptan $80 \mathrm{mg}$ (not an approved dose in Canada), and almotriptan $12.5 \mathrm{mg}$ provided the highest likelihood of consistent success over multiple attacks (intrapatient consistency; headache response and pain-free at $2 \mathrm{~h}$ ); however, sumatriptan featured the longest clinical experience and widest range of formulations. Rizatriptan $10 \mathrm{mg}$ was superior to sumatriptan $100 \mathrm{mg}$ in terms of efficacy (sustained pain freedom at $24 \mathrm{~h}$ ) and consistency. Eletriptan $80 \mathrm{mg}$ was superior to sumatriptan $100 \mathrm{mg}$ in terms of efficacy (pain relief at $2 \mathrm{~h}$ and sustained pain freedom at $24 \mathrm{~h}$ ) but was associated with lower tolerability. Almotriptan $12.5 \mathrm{mg}$ showed better sustained pain freedom compared to sumatriptan $100 \mathrm{mg}$, combined with good tolerability. ${ }^{14,15}$

A systematic review of double-blind, randomized, clinical trials of oral triptans reporting data after a single migraine attack was published in 2007; this analysis did not include raw data submitted by pharmaceutical companies, only published trials. ${ }^{16}$ The main objective was to compare the efficacy and tolerability of seven currently marketed oral, non-re-encapsulated triptan formulations (almotriptan, eletriptan, frovatriptan, naratriptan, rizatriptan, sumatriptan, and zolmitriptan) versus placebo for the treatment of moderate-to-severe migraine attacks. Out of 221 publications reviewed, 38 studies were included in the analysis. All of the triptans provided significant relief (i.e., headache response) and/or absence of pain at $2 \mathrm{~h}$ (i.e., pain-free), as well as relief of pain (i.e., headache response) at $1 \mathrm{~h}$, when compared with placebo. After 30 minutes, rizatriptan $10 \mathrm{mg}$ (regular and orally disintegrating tablets), sumatriptan 50 and $100 \mathrm{mg}$ (fast dissolving tablets), and sumatriptan $50 \mathrm{mg}$ (regular tablets) showed significant headache response compared to placebo; fast-dissolving sumatriptan $100 \mathrm{mg}$ was the only oral triptan that was superior to placebo for the pain-free endpoint at 30 minutes. Eletriptan $40 \mathrm{mg}$ and fast-dissolving sumatriptan $50 \mathrm{mg}$ and $100 \mathrm{mg}$ showed a lower rate of recurrence than placebo at 24 hours, whereas rizatriptan $10 \mathrm{mg}$ tablets showed a greater rate of recurrence than placebo.

Another systematic review was undertaken to consolidate evidence concerning safety and efficacy of triptans available in Canada at the time of publication in 2001 (sumatriptan, rizatriptan, naratriptan, zolmitriptan), and to provide guidelines for selection of a triptan. ${ }^{17}$ Data from published, randomized, placebo-controlled trials were pooled. A combined number need to treat $(\mathrm{NNT})$ and number needed to harm $(\mathrm{NNH})$ was generated for each triptan. The lowest NNT (highest efficacy) for headache response/pain-free at $2 \mathrm{~h}$ was observed with subcutaneous sumatriptan. Among the oral triptans, the lowest NNT was observed with rizatriptan (highest efficacy), and the highest NNT with naratriptan (lowest efficacy). The lowest NNH (i.e., most harm) was seen with subcutaneous sumatriptan. Rizatriptan appeared to provide earlier and better relief of migraineassociated nausea than the other oral triptans (i.e., naratriptan, sumatriptan, zolmitriptan). The authors concluded that all of the currently available triptans are effective symptomatic medications for acute migraine attacks. Sumatriptan had the most extensive data supporting its efficacy, tolerability, and safety; however, the newer triptans have some advantages over sumatriptan. Although there are differences among the triptans, they appear to be relatively small. ${ }^{17}$

\section{Individual triptan meta-analyses (see Table 3)}

Individual meta-analyses have been published for the following triptans: sumatriptan (oral, subcutaneous, intranasal), naratriptan, frovatriptan, almotriptan, and zolmitriptan.

\section{Triptans versus triptans (see Table 4)}

There are relatively few randomized, controlled, head-tohead trials comparing triptans to each other. Most head-to-head trials compare oral sumatriptan to one of the other triptans, and have utilized the 2 -h headache response as a primary efficacy 
measure $(2 \mathrm{~h}$ pain-free response is a preferred endpoint in clinical trials). ${ }^{9}$

Although all seven triptans available in Canada show significant efficacy and good tolerability, and the differences between them are relatively small, head-to-head trials do support the presence of some differences. Unfortunately, comparison trials do not exist for all the triptans, and there are concerns that the results of some of them may have been affected by encapsulation. Based on available trials, it is possible to draw some conclusions, recognizing that the response of the individual patient to a specific triptan cannot be predicted, and as has often been said, the differences among patients appear greater than the differences among the triptans themselves. Rizatriptan $(10 \mathrm{mg}$ ) does tend to provide faster headache relief compared to a number of other oral triptans, and better relief of nausea than sumatriptan. Eletriptan (40 mg) may show a greater sustained 24 hour response rate than sumatriptan, due at least in part to a relatively low headache recurrence rate. Almotriptan (12.5 mg) tends to show a lower adverse event rate than some other triptans (zolmitriptan and sumatriptan). Naratriptan and frovatriptan tend to have a slower onset of action and, therefore, a lower response rate at early time points after treatment, although in the direct comparison trials (see Table 4), frovatriptan $(2.5 \mathrm{mg}$ ) appears to show similar efficacy at $2 \mathrm{~h}$ compared to several other triptans. These studies were relatively small with limited power to detect differences, however, and should therefore be interpreted with caution.

\section{Triptans versus ASA and NSAIDs (see Table 5)}

Overall, results of comparative trials have indicated that NSAIDs are generally as effective as triptans (see Acetylsalicylic acid and NSAIDs sections). However, experience in clinical practice suggests that oral triptans are superior to non-specific acute treatments in many patients (see "Triptans versus nontriptans: summary").

\section{Triptans versus ergot derivatives}

Triptans have shown superior efficacy over ergotamine/ caffeine in acute migraine (see Ergotamine section).

\section{Triptans versus non-triptans - summary}

There are relatively few randomized, controlled trials comparing triptans to other classes of acute migraine medications. Most of the trials compared sumatriptan to other drugs. In many of the trials, differences between triptans and other acute migraine medications on primary endpoints were not dramatic. In a review of published trials comparing oral triptans with non-triptans in 2004, Lipton et al found that data suggested a significantly greater benefit with triptans than ergotamine, but no significant difference between triptans and NSAIDs or other

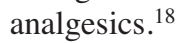

However, experience in clinical practice suggests that oral triptans are superior to non-specific acute treatments in many patients. Thus, there appears to be a discrepancy between clinical trial results and clinical experience. Several explanations have been proposed for this discrepancy: statistically significant differences may not have been noted due to lack of adequate statistical power in clinical trials; patient selection, whereby patients treated with triptans in clinical practice may be relatively more responsive to triptans and less responsive to other agents than patients participating in clinical trials; headache response at $2 \mathrm{~h}$, an endpoint in many clinical trials, may not fully capture the benefits of triptans relative to other agents, as assessed in clinical practice; waiting until pain is moderate or severe, as required in most clinical trials, may disadvantage triptans relative to comparators, whereas early treatment during mild pain may increase the benefit of triptans versus other classes of drugs. ${ }^{18}$

\section{Triptans combined with NSAIDs}

Since multiple peripheral and central neural mechanisms may be involved in migraine pathophysiology, drug combinations may potentially achieve better response rates than single drugs. A few studies have evaluated the efficacy of triptans combined with NSAIDs.

A multicentre, randomized, double-blind, double-dummy, placebo-controlled, four-arm study $(n=972)$ evaluated the efficacy and tolerability of the combination of oral sumatriptan $50 \mathrm{mg}$ (encapsulated) and naproxen sodium $500 \mathrm{mg}$ (as two separate tablets). ${ }^{19}$ Patients treated a single moderate or severe migraine attack with placebo, naproxen sodium $500 \mathrm{mg}$, sumatriptan $50 \mathrm{mg}$, or a combination of sumatriptan $50 \mathrm{mg}$ and naproxen sodium $500 \mathrm{mg}$; in the latter two treatment arms, sumatriptan tablets were encapsulated in order to achieve blinding of the study. The primary endpoint was 24-h "sustained pain response" (pain no greater than mild at $2 \mathrm{~h}$ post-dose, taking no rescue medications for $24 \mathrm{~h}$ post-dose, and having no recurrence of moderate or severe pain within $24 \mathrm{~h}$ of the initial dose). In the sumatriptan plus naproxen sodium group, $46 \%$ of subjects achieved a 24-h sustained pain response, which was significantly more effective than sumatriptan alone (29\%), naproxen sodium alone $(25 \%)$, or placebo $(17 \% ; \mathrm{p}<0.001)$. There was no significant increase in the incidence of adverse effects with the combination compared to monotherapy with sumatriptan. Encapsulation of sumatriptan for blinding purposes may have altered its pharmacokinetic profile and thereby, possibly decreased efficacy responses. ${ }^{19}$

The superiority of fixed-combination sumatriptan/naproxen sodium (85/500 mg; not currently available in Canada) vs. sumatriptan $85 \mathrm{mg}$ (monotherapy) or naproxen sodium $500 \mathrm{mg}$ (monotherapy) was demonstrated in a publication reporting the results of two identically designed randomized, placebocontrolled trials $(n=3413) .^{20}$ In both studies, the fixedcombination resulted in a significantly higher 2 -h headache relief rate (defined as pain reduction from moderate or severe to mild or no pain) than sumatriptan monotherapy (65\% vs. $55 \%$, respectively, $\mathrm{p}=0.009$ in study $1 ; 57 \%$ vs. $50 \%, \mathrm{p}=0.02$ in study 2).

Two replicate, multicentre, randomized, double-blind, placebo-controlled, 2-attack, crossover trials ( $\mathrm{n}=144$, study 1; $\mathrm{n}=139$, study 2) evaluated the efficacy of a fixed-dose formulation of sumatriptan $85 \mathrm{mg}$ and naproxen sodium $500 \mathrm{mg}$ (vs. placebo) in migraineurs who had discontinued treatment with a short-acting triptan in the past year because of poor response or intolerance (note: fixed-dose formulation is not available in Canada). ${ }^{21}$ Patients had discontinued an average of 3.3 triptans before study entry. Patients were instructed to treat 
Table 3: Individual triptan meta-analyses [part 1] ${ }^{45,83-88}$

\begin{tabular}{|c|c|c|c|}
\hline $\begin{array}{c}\text { Drug \& route (publication date); } \\
\text { number of trials included; number of } \\
\text { participants (n); types of participants }\end{array}$ & Objective & Efficacy outcomes and main results & Conclusions and limitations \\
\hline $\begin{array}{l}\text { Sumatriptan oral }(2012)^{45} \\
61 \text { RCTs ( } 24 \text { vs. placebo only; } 13 \text { vs. active } \\
\text { comparator only; } 24 \text { vs. placebo \& active } \\
\text { comparator) } \\
n=37,250 \\
\text { Types of participants: } \\
\text { adults ( } \geq 18 \text { years); IHS criteria for migraine } \\
\text { diagnosis; stable prophylactic therapy } \\
\text { allowed }\end{array}$ & $\begin{array}{l}\text { To determine } \\
\text { efficacy \& } \\
\text { tolerability of oral } \\
\text { sumatriptan vs. } \\
\text { placebo \& other } \\
\text { active interventions } \\
\text { in treatment of } \\
\text { acute migraine } \\
\text { attacks in adults }\end{array}$ & $\begin{array}{l}\text { Primary efficacy outcomes: pain-free at } 1 \mathrm{~h} \& 2 \mathrm{~h} \text { (no rescue medication); } \\
\text { headache relief at } 1 \mathrm{~h} \& 2 \mathrm{~h} \text {; sustained pain-free during } 24 \mathrm{~h} \text { post-dose (pain-free } \\
\text { at } 2 \mathrm{~h} \& \text { no use of rescue medication or recurrence of moderate to severe pain } \\
\text { within } 24 \mathrm{~h} \text { ); sustained headache relief during } 24 \mathrm{~h} \text { post-dose (headache relief at } 2 \\
\mathrm{~h} \text {, sustained for } 24 \mathrm{~h} \text {, with no use of rescue medication or second dose of study } \\
\text { medication) } \\
\text { Direct comparisons with other active treatments: other triptans, acetaminophen, } \\
\text { ASA, NSAIDs, \& ergotamine combinations } \\
\text { Main results: For sumatriptan } 50 \mathrm{mg} \text { vs. placebo: Pain-free at } 2 \mathrm{~h}: 28 \% \text { vs. } 11 \% \\
\text { (NNT=6.1) Headache relief at } 2 \mathrm{~h}: 57 \% \text { vs. } 32 \% \text { (NNT=4.0) Sustained pain-free } \\
\text { (24 h): } 17 \% \text { vs. } 7 \% \text { (NNT = } 9.5 \text { ) } \\
\text { For sumatriptan } 100 \mathrm{mg} \text { vs. placebo: Pain-free at } 2 \mathrm{~h}: 32 \% \text { vs. } 11 \% \text { (NNT=4.7) } \\
\text { Headache relief at } 2 \mathrm{~h}: 61 \% \text { vs. } 32 \% \text { (NNT=3.5) Sustained pain-free ( } 24 \mathrm{~h}): 24 \% \\
\text { vs. } 8 \% \text { (NNT=6.5) } \\
\text { For sumatriptan } 50 \mathrm{mg} \text { vs. effervescent ASA } 1,000 \mathrm{mg} \text { : Pain-free at } 2 \mathrm{~h}: 32 \% \text { vs. } \\
26 \% \text { (NS) } \\
\text { For sumatriptan } 100 \mathrm{mg} \text { vs. ASA } 900 \mathrm{mg}+\text { metoclopramide } 10 \mathrm{mg} \text { : } \\
\text { Pain-free at } 2 \mathrm{~h}: 26 \% \text { vs. } 16 \% \text {; NNT=10 in favour of sumatriptan } \\
\text { For sumatriptan } 50 \mathrm{mg} \text { vs. rizatriptan } 10 \mathrm{mg} \text { : Pain-free at } 2 \mathrm{~h}: 35 \% \text { vs. } 39 \% \text { (NS) } \\
\text { For sumatriptan } 100 \mathrm{mg} \text { vs. rizatriptan } 10 \mathrm{mg} \text { : Pain-free at } 2 \mathrm{~h}: 31 \% \text { vs. } 37 \% \text {; } \\
\text { NNT=16 in favour of rizatriptan } \\
\text { For sumatriptan } 50 \mathrm{mg} \text { vs. eletriptan } 40 \mathrm{mg} \text { : Pain-free at } 2 \mathrm{~h}: 18 \% \text { vs. } 24 \% \text {; } \\
\text { NNT=16 in favour of eletriptan } \\
\text { For sumatriptan } 100 \mathrm{mg} \text { vs. eletriptan } 40 \mathrm{mg} \text { : Pain-free at } 2 \mathrm{~h}: 24 \% \text { vs. } 32 \% \text {; } \\
\text { NNT=12 in favour of eletriptan } \\
\text { For sumatriptan } 100 \mathrm{mg} \text { vs. almotriptan } 12.5 \mathrm{mg} \text { : Pain-free at } 2 \mathrm{~h}: 33 \% \mathrm{vs.} 28 \% \\
\text { (NS) }\end{array}$ & $\begin{array}{l}\text { Oral sumatriptan is effective as an abortive } \\
\text { treatment for acute migraine attacks, relieving } \\
\text { pain, nausea, photophobia, phonophobia, \& } \\
\text { functional disability but is associated with } \\
\text { increased AEs vs. placebo. } \\
\text { Results for } 25 \mathrm{mg} \text { dose were similar to } 50 \mathrm{mg} \\
\text { dose, while } 100 \mathrm{mg} \text { dose was significantly better } \\
\text { than } 50 \mathrm{mg} \text { for pain-free and headache relief at } 2 \\
\text { h. } \\
\text { Data support general guideline to use } 50 \mathrm{mg} \text { as } \\
\text { starting dose, with increases to } 100 \mathrm{mg} \text {, if } \\
\text { necessary \& tolerated (some patients may find a } \\
25 \text { mg dose is sufficient). } \\
\text { Treating early, during mild pain phase, gave } \\
\text { significantly better NNTs for pain-free at } 2 \mathrm{~h} \text { and } \\
\text { sustained pain-free at } 24 \text { h than did treating } \\
\text { established attacks with moderate or severe pain } \\
\text { intensity. } \\
\text { AEs: mostly mild to moderate severity, self- } \\
\text { limiting; clear dose response relationship ( } 25 \mathrm{mg} \\
\text { to } 100 \mathrm{mg} \text { ); serious AEs uncommon } \\
\text { Limitations: most studies industry-sponsored } \\
\text { using brand name; no generic sumatriptan trials } \\
\text { found; limited data on sustained pain relief or } \\
\text { pain-free ( } 24 \text { or } 48 \text { h); more early intervention } \\
\text { studies needed }\end{array}$ \\
\hline $\begin{array}{l}\text { Sumatriptan subcutaneous (SC) }(2012)^{83} \\
35 \text { RCTs ( } 28 \text { vs. placebo; } 3 \text { vs. active } \\
\text { comparator only; } 4 \text { vs. placebo \& active } \\
\text { comparator) } \\
\mathrm{n}=9365 \\
\text { Types of participants: } \\
\text { adults ( } \geq 18 \text { years); IHS criteria for migraine } \\
\text { diagnosis; stable prophylactic therapy } \\
\text { allowed }\end{array}$ & $\begin{array}{l}\text { To determine } \\
\text { efficacy \& } \\
\text { tolerability of SC } \\
\text { sumatriptan vs. } \\
\text { placebo and other } \\
\text { active interventions } \\
\text { in treatment of } \\
\text { acute migraine } \\
\text { attacks in adults }\end{array}$ & $\begin{array}{l}\text { Primary efficacy outcomes: pain-free at } 1 \mathrm{~h} \& 2 \mathrm{~h} \text { (no rescue medication); } \\
\text { headache relief at } 1 \mathrm{~h} \& 2 \mathrm{~h} \text {; sustained pain-free during } 24 \mathrm{~h} \text { post-dose (pain-free } \\
\text { at } 2 \mathrm{~h} \& \text { no use of rescue medication or recurrence of moderate to severe pain } \\
\text { within } 24 \mathrm{~h} \text { ); sustained headache relief during } 24 \mathrm{~h} \text { post-dose (headache relief at } 2 \\
\mathrm{~h} \text {, sustained for } 24 \mathrm{~h} \text {, with no use of rescue medication or second dose of study } \\
\text { medication) } \\
\text { Main results: For sumatriptan } 6 \mathrm{mg} \text { SC vs. placebo: Pain-free at } 1 \mathrm{~h}: 41 \% \mathrm{vs.} \\
7 \% \text { (NNT }=2.9 \text { ) Pain-free at } 2 \mathrm{~h}: 59 \% \text { vs. } 15 \% \text { (NNT }=2.3 \text { ) Headache relief at } 1 \mathrm{~h} \text { : } \\
71 \% \text { vs. } 26 \% \text { (NNT=2.2) Headache relief at } 2 \mathrm{~h}: 79 \% \text { vs. } 31 \% \text { (NNT=2.1) } \\
\text { Sustained pain-free ( } 24 \mathrm{~h} \text { ): } 31 \% \text { vs. } 15 \% \text { (NNT=6.1) } \\
\text { Sumatriptan SC vs. active comparators [SC naratriptan (not available in Canada); } \\
\text { IV ASA (not available in Canada); oral effervescent ASA + metoclopramide; IN } \\
\& \text { SC DHE] - insufficient data for a pooled analysis } \\
\text { AEs: mostly mild to moderate, self-limiting; serious AEs (overall) }=0.25 \% \text {; for } \\
\text { sumatriptan } 6 \text { mg vs. placebo: NNH=4.9 }\end{array}$ & $\begin{array}{l}\text { SC sumatriptan is an effective abortive treatment } \\
\text { for acute migraine attacks, quickly relieving pain, } \\
\text { nausea, photophobia, phonophobia, and functional } \\
\text { disability, but is associated with increased AEs vs. } \\
\text { placebo. } \\
\text { Most data is for } 6 \mathrm{mg} \text { dose; data suggest a } 4 \mathrm{mg} \\
\text { dose (where available) may be a sensible starting } \\
\text { dose, with increase to } 6 \mathrm{mg} \text {, if response is } \\
\text { inadequate \& higher dose is tolerated. } \\
\text { No evidence that taking second dose of } \\
\text { sumatriptan } 6 \text { mg in event of inadequate response } \\
1 \text { h after initial dose has significant impact on } \\
\text { headache relief by } 2 \text { h. } \\
\text { AEs: mostly mild to moderate \& short duration; } \\
\text { serious AEs uncommon } \\
\text { Limitations: only } 5 \text { studies provided } 24 \mathrm{~h} \\
\text { sustained efficacy data; no early intervention } \\
\text { studies when pain is mild }\end{array}$ \\
\hline $\begin{array}{l}\text { Sumatriptan intranasal (IN) }(2012)^{84} \\
12 \text { RCTs (10 vs. placebo only; } 2 \text { vs. active } \\
\text { comparators) } \\
n=4755 \\
\text { Types of participants: } \\
\text { adults ( } \geq 18 \text { years); IHS criteria for migraine } \\
\text { diagnosis; stable prophylactic therapy } \\
\text { allowed }\end{array}$ & $\begin{array}{l}\text { To determine } \\
\text { efficacy \& } \\
\text { tolerability of IN } \\
\text { sumatriptan } \\
\text { compared to } \\
\text { placebo \& other } \\
\text { active interventions } \\
\text { in the treatment of } \\
\text { acute migraine } \\
\text { attacks in adults }\end{array}$ & $\begin{array}{l}\text { Primary efficacy outcomes: pain-free at } 1 \mathrm{~h} \& 2 \mathrm{~h} \text { (no rescue medication); } \\
\text { headache relief at } 1 \mathrm{~h} \& 2 \mathrm{~h} \text {; sustained pain-free during } 24 \mathrm{~h} \text { post-dose (pain-free } \\
\text { at } 2 \mathrm{~h} \& \text { no use of rescue medication or recurrence of moderate to severe pain } \\
\text { within } 24 \mathrm{~h} \text { ); sustained headache relief during } 24 \mathrm{~h} \text { post-dose (headache relief at } 2 \\
\mathrm{~h} \text {, sustained for } 24 \mathrm{~h} \text {, with no use of rescue medication or second dose of study } \\
\text { medication) } \\
\text { Main results: Sumatriptan } 20 \mathrm{mg} \text { vs. placebo: Pain-free at } 2 \mathrm{~h}: 32 \% \text { vs. } 11 \% \\
\text { (NNT=4.7) Headache relief at } 1 \mathrm{~h} \text { : } 46 \% \text { vs. } 25 \% \text { (NNT=4.9) Headache relief at } 2 \\
\text { h: } 61 \% \text { vs. } 32 \% \text { (NNT=3.5) } \\
\text { Active comparators ( } 2 \text { trials): sumatriptan } 20 \mathrm{mg} \text { IN vs. DHE } 1 \mathrm{mg} \text { : no usable } \\
\text { data; sumatriptan } 20 \mathrm{mg} \text { IN vs. rizatriptan (ODT) } 10 \mathrm{mg} \text { : rizatriptan had higher } \% \\
\text { headache relief at } 2 \mathrm{~h}(71 \% \text { vs. } 65 \% \text { ) \& relief of associated symptoms at } 2 \mathrm{~h} \\
\text { AEs: mild to moderate severity, self-limiting; serious AEs uncommon; taste } \\
\text { disturbance significantly higher incidence for sumatriptan IN } 10 / 20 \mathrm{mg} \text { vs. } \\
\text { placebo ( } 22-30 \% \text { vs. } 1 \% \text {; NNH=3.5 \& 4.8, respectively) }\end{array}$ & $\begin{array}{l}\text { IN sumatriptan is effective as an abortive } \\
\text { treatment for acute migraine attacks, relieving } \\
\text { pain, nausea, photophobia, phonophobia, \& } \\
\text { functional disability, with single doses of } 10 \mathrm{mg} \text { or } \\
\text { more providing clinically useful levels of relief, } \\
\text { but is associated with increased AEs vs. placebo. } \\
\text { Data suggest that a } 10 \mathrm{mg} \text { dose may be a sensible } \\
\text { starting dose (depending on availability; } 5 \text {-mg and } \\
20 \text {-mg strengths are available in Canada), with } \\
\text { increase to } 20 \mathrm{mg} \text {, if there is an inadequate } \\
\text { response. } \\
\text { AEs: increased vs. placebo; most AEs mild \& of } \\
\text { short duration. } \\
\text { Limitations: insufficient evidence to address } \\
\text { several important primary \& secondary outcomes } \\
\text { (e.g., } 24 \mathrm{~h} \text { sustained efficacy; } 1 \mathrm{~h} \\
\text { pain-free); lack of early interventions studies } \\
\text { when pain is mild }\end{array}$ \\
\hline
\end{tabular}


Table 3: Individual triptan meta-analyses [part 2] continued

\begin{tabular}{|c|c|c|c|}
\hline $\begin{array}{l}\text { Zolmitriptan oral, intranasal }(2008)^{85} \\
24 \text { RCTs; } n=15,408 \text { (ages 12-65) } \\
\text { Types of participants: } \\
\text { adults (18-65 years) and/or adolescents (12- } \\
17 \text { years); IHS criteria for migraine } \\
\text { diagnosis }\end{array}$ & $\begin{array}{l}\text { To assess relative } \\
\text { efficacy and } \\
\text { tolerability of } \\
\text { different } \\
\text { formulations of } \\
\text { zolmitriptan } \\
\text { compared with } \\
\text { placebo, active } \\
\text { comparators, or } \\
\text { different dosage } \\
\text { forms of } \\
\text { zolmitriptan in } \\
\text { acute migraine } \\
\text { attacks }\end{array}$ & $\begin{array}{l}\text { Efficacy outcomes*: \% of pts with: (1) headache relief at } 1 \mathrm{~h} \text { and } 2 \mathrm{~h} \text { post-dose; } \\
\text { (2) pain-free at } 1 \mathrm{~h} \text { and } 2 \mathrm{~h} \text { post-dose; (3) sustained pain-free response over } 24 \mathrm{~h} \\
\text { post-dose; primary outcomes: headache relief and pain-free responses at } 2 \mathrm{~h} \\
\text { post-dose } \\
\text { Results: All } 3 \text { formulations of zolmitriptan were significantly more effective vs. } \\
\text { placebo for all efficacy outcomes. } \\
\text { For } 2 \text {-h pain free rates: zolmitriptan } 2.5 \mathrm{mg} \text { tablet was as effective as almotriptan } \\
12.5 \mathrm{mg} \text {, eletriptan } 40 \mathrm{mg} \text {, sumatriptan } 50 \& 100 \mathrm{mg} \text {, and more effective than } \\
\text { naratriptan } 2.5 \mathrm{mg} \text {. } \\
\text { Zolmitriptan } 5 \mathrm{mg} \text { nasal spray had faster onset of action and greater efficacy vs. } \\
\text { zolmitriptan } 2.5 \mathrm{mg} \text { tablet. } \\
\text { Zolmitriptan } 2.5 \mathrm{mg} \text { had lower risks of AEs than eletriptan } 80 \mathrm{mg} \text {, but higher } \\
\text { risks than naratriptan } 2.5 \mathrm{mg} \text { or rizatriptan } 10 \mathrm{mg} \text {. }\end{array}$ & 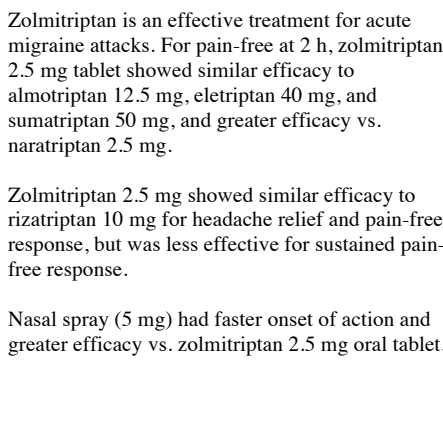 \\
\hline $\begin{array}{l}\text { Naratriptan oral }(2004)^{86} \\
10 \text { RCTs (9 DB) } \\
\mathrm{n}=4499 \text { (ages 18-65) } \\
\text { Types of participants: } \\
\text { adults (18-65 years); IHS criteria for } \\
\text { migraine diagnosis }\end{array}$ & $\begin{array}{l}\text { To evaluate } \\
\text { comparative } \\
\text { efficacy and } \\
\text { tolerability of } \\
\text { naratriptan in acute } \\
\text { migraine attacks }\end{array}$ & 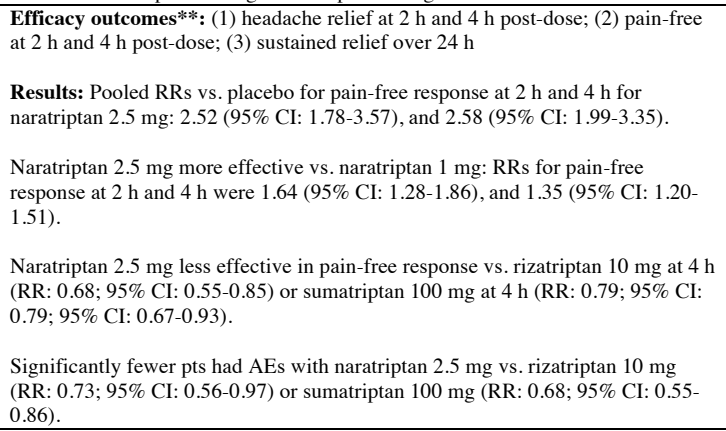 & $\begin{array}{l}\text { Naratriptan is effective and well-tolerated for } \\
\text { acute migraine attacks; } 2.5 \mathrm{mg} \text { dose is } \\
\text { significantly more effective vs. } 1 \mathrm{mg} \text { dose. } \\
\text { Rizatriptan } 10 \mathrm{mg} \text { and sumatriptan } 100 \mathrm{mg} \text { are } \\
\text { superior to naratriptan for headache relief. } \\
\text { Zolmitriptan } 2.5 \mathrm{mg} \text { is comparable in efficacy to } \\
\text { naratriptan } 2.5 \mathrm{mg} \text { (note: this was based on one } \\
\text { trial, which was stopped early due to supply } \\
\text { problems). } \\
\text { Naratriptan is associated with lower incidence of } \\
\text { AEs vs. rizatriptan, sumatriptan, and zolmitriptan; } \\
\text { overall rate of AEs for naratriptan is similar to } \\
\text { placebo. }\end{array}$ \\
\hline $\begin{array}{l}\text { Frovatriptan oral }(2005)^{87} \\
5 \text { RCTs } \\
n=2866 \\
\text { Types of participants: } \\
\text { moderate or severe migraine attacks }\end{array}$ & $\begin{array}{l}\text { To evaluate } \\
\text { efficacy and } \\
\text { tolerability of } \\
\text { frovatriptan in } \\
\text { acute migraine }\end{array}$ & $\begin{array}{l}\text { Frovatriptan } 2.5 \mathrm{mg} \text { more effective vs. placebo for pain-free (RR } 3.70 ; 95 \% \mathrm{CI} \text { : } \\
2.59-5.29 ; p<0.0001 \text { at } 2 \mathrm{~h} \text {, and } 2.67 ; 95 \% \mathrm{CI}: 2.21-3.22, p<0.0001 \text { at } 4 \mathrm{~h} \text { ). } \\
\text { Frovatriptan also superior to placebo in reducing headache severity: pooled RR } \\
1.66 \text { at } 2 \mathrm{~h}(95 \% \mathrm{CI}: 1.48-1.88 ; p<0.0001) \text {, and } 1.83 \text { at } 4 \mathrm{~h} \text { (95\% CI: } 1.66-2.00 ; \\
p<0.0001) . \\
\text { Risk of headache recurrence reduced by } 26 \% \text { with frovatriptan vs. placebo (RR } \\
0.74 ; 95 \% \text { CI: } 0.59-0.93 ; p=0.009) \text {. } \\
\text { Frovatriptan also superior vs. placebo in improving symptoms associated with } \\
\text { migraine (nausea, photophobia, phonophobia). } \\
\text { Frovatriptan caused more AEs vs. placebo (RR } 1.31 ; 95 \% \mathrm{CI}: 1.07-1.62 ; p=0.01 \text { ). }\end{array}$ & $\begin{array}{l}\text { Frovatriptan is more effective but may cause more } \\
\text { AEs than placebo in acute moderate to severe } \\
\text { migraine. }\end{array}$ \\
\hline $\begin{array}{l}\text { Almotriptan oral }(2007)^{88} \\
8 \text { RCTs } \\
n=4995 \\
\text { Types of participants: } \\
\text { aduIts; IHS criteria for migraine diagnosis }\end{array}$ & $\begin{array}{l}\text { To evaluate } \\
\text { comparative } \\
\text { efficacy and safety } \\
\text { of almotriptan in } \\
\text { acute migraine } \\
\text { attacks }\end{array}$ & $\begin{array}{l}\text { Almotriptan } 12.5 \mathrm{mg} \text { significantly more effective vs. placebo for all efficacy } \\
\text { outcomes (RRs ranged from } 1.47 \text { to } 2.15 \text {; ARDs ranged from } 0.01 \text { to } 0.28 \text { ); no } \\
\text { significant differences in any safety outcomes. } \\
\text { No significant differences in efficacy outcomes comparing almotriptan } 12.5 \mathrm{mg} \\
\text { vs. sumatriptan } 100 \mathrm{mg} \& \text { vs. zolmitriptan } 2.5 \mathrm{mg} \text {. } \\
\text { Almotriptan } 12.5 \mathrm{mg} \text { associated with significantly fewer AEs vs. sumatriptan } 100 \\
\text { mg (RR: } 0.39 ; 95 \% \text { CI: } 0.23,0.67 \text { ); however, no significant differences between } \\
\text { almotriptan and sumatriptan for clinically important AEs (e.g., dizziness, } \\
\text { somnolence, asthenia, chest tightness). }\end{array}$ & $\begin{array}{l}\text { Almotriptan } 12.5 \mathrm{mg} \text { is an effective treatment for } \\
\text { acute migraine attacks; found to be as effective as } \\
\text { sumatriptan } 100 \mathrm{mg} \& \text { zolmitriptan } 2.5 \mathrm{mg} \text { for } 2-\mathrm{h} \\
\text { headache relief and pain-free } \\
\text { Risk of AEs for almotriptan } 12.5 \mathrm{mg} \text { was similar } \\
\text { to placebo \& significantly lower than sumatriptan } \\
100 \mathrm{mg} \text {. }\end{array}$ \\
\hline
\end{tabular}

*Headache relief defined as decrease from initial moderate or severe headache to mild or none; pain-free response defined as reduction in headache severity from mild, moderate, or severe to no pain; sustained pain-free response defined as pain-free at $2 \mathrm{~h}$ post-dose, no pain from 2 to $24 \mathrm{~h}$ as well as use of no rescue medication or a second dose of study drug.**Headache relief defined as decrease from initial moderate or severe headache to none or mild at 2 and $4 \mathrm{~h}$ post-dose; pain-free defined as headache reduced from moderate or severe to none at 2 and $4 \mathrm{~h}$ post-dose; sustained relief over $24 \mathrm{~h}$ defined as headache relief at $4 \mathrm{~h}$ post-dose, maintained for $24 \mathrm{~h}$ after treatment (i.e., pain did not return to moderate or severe), with no use of rescue medication or a second dose of study medication. RCTs = randomized; controlled trials; IHS = International Headache Society; CI = confidence interval; AEs = adverse events; ODT = orally disintegrating tablet; RR (risk ratio) for efficacy = proportion of patients achieving outcome in treatment group relative to control group; $\mathrm{CI}=$ confidence interval; $\mathrm{RR}$ for $\mathrm{AEs}=$ relative risk; $\mathrm{RRs}=$ pooled rate ratios; $\mathrm{ARDs}=\mathrm{absolute}$ rate differences; NNT = number-needed-to-treat; $\mathrm{NNH}=$ number-needed-to-harm; NS = not significant

within one hour, while pain was mild. Sumatriptan/naproxen was superior $(\mathrm{p}<0.001)$ to placebo for 2- through 24-h sustained painfree response (primary endpoint) (study 1: $26 \%$ vs. $8 \%$; study 2: $31 \%$ vs. $8 \%$ ), and for pain-free response at $2 \mathrm{~h}$ (study 1: $40 \%$ vs. $17 \%$; study 2 : $44 \%$ vs. $14 \%$ ). Sumatriptan/naproxen was generally well tolerated.

\section{Triptan non-responders (switching triptans)}

Oral triptan therapy does not provide headache relief in approximately one-third of patients. ${ }^{14}$ Since response to a single triptan is not predictable in an individual patient, it may be useful to test a range of different triptans in an individual, in order to select the "ideal triptan" in terms of effectiveness and tolerability 
for that patient. Evidence from clinical trials indicates that patients with a poor response to one triptan can benefit from subsequent treatment with a different triptan. ${ }^{22-26}$ When switching to another triptan, it is generally recommended (according to Product Monographs) to wait 24 hours before using a different triptan.

A multiple attack study evaluated the efficacy and tolerability of five triptans commercially available in Italy (zolmitriptan $2.5 \mathrm{mg}$, rizatriptan $10 \mathrm{mg}$, sumatriptan $100 \mathrm{mg}$, almotriptan $12.5 \mathrm{mg}$, and eletriptan $40 \mathrm{mg}$ ); 30 patients completed the study. ${ }^{22}$ For a total of 30 attacks, patients used a different triptan or placebo for every five consecutive attacks. Different sequences of the five triptans and of the placebo were used. The primary endpoints evaluated were: headache response at $2 \mathrm{~h}$, pain-free at $2 \mathrm{~h}$, and sustained pain-free (at $24 \mathrm{~h}$ ); intra-patient consistency (percentage of patients obtaining relief in one or three or five of five consecutively treated attacks), and tolerability. No substantial difference in terms of efficacy of the triptans was noted, and all were well tolerated. Although results of this study are of clinical interest, with the small number of subjects $(n=30)$, this study would have limited power to detect differences among triptans.

A study evaluated the efficacy and tolerability of almotriptan $12.5 \mathrm{mg}$ in migraine patients who responded poorly to oral sumatriptan $50 \mathrm{mg}$ (at least two unsatisfactory responses). Patients treated their first attack with open-label sumatriptan $50 \mathrm{mg}$. Of the 198 sumatriptan non-responders who treated their second attack (99 almotriptan, 99 placebo), 2-h pain relief rates were significantly higher with almotriptan compared to placebo (47.5 vs. $23.2 \%, \mathrm{p}<0.001$ ); a significant difference was also seen in pain-free rates at $2 \mathrm{~h}(33.3$ vs. $14.1 \%, \mathrm{p}<0.005)$. The authors concluded that almotriptan $12.5 \mathrm{mg}$ is an effective and well tolerated alternative for patients who respond poorly to sumatriptan $50 \mathrm{mg}^{24}$

In a double-blind, placebo-controlled, parallel group, multicentre study, the tolerability and efficacy of eletriptan was studied in patients $(n=446)$ who had discontinued oral sumatriptan due to lack of efficacy or intolerable adverse events. Patients were randomized to eletriptan $40 \mathrm{mg}$ (E40) or $80 \mathrm{mg}$ (E80), or placebo for treatment of up to three migraine attacks. Two-hour response rates (first-dose, first-attack data) were 59\% for eletriptan $40 \mathrm{mg}, 70 \%$ for eletriptan $80 \mathrm{mg}$, and $30 \%$ for placebo $(\mathrm{p}<0.0001$ for both doses of eletriptan vs. placebo; $\mathrm{p}<0.05$ for E80 vs. E40). Onset of action was rapid, with 1-h headache response rates significantly superior for E40 and E80 compared to placebo. Both E40 and E80 demonstrated significant consistency of response compared to placebo in at least two of three attacks. Adverse events were mild to moderate in severity and dose-related. The authors concluded that eletriptan $(40 \mathrm{mg}$ or $80 \mathrm{mg}$ ) produced an effective response in patients who had previously discontinued treatment with sumatriptan. ${ }^{25}$

In a randomized, double-blind, placebo-controlled study of naratriptan in 347 migraine sufferers non-responsive to sumatriptan (self-described), patients' poor response was confirmed by a single-blind assessment with sumatriptan $50 \mathrm{mg}$ for the treatment of one moderate to severe migraine attack. Patients confirmed as non-responsive (no pain relief at $4 \mathrm{~h}$; nonresponse confirmed in $63.4 \%$ of patients) were randomized to naratriptan $2.5 \mathrm{mg}$ or placebo for treatment of the next migraine attack. Naratriptan was found to be statistically superior to placebo for relief of headache pain at $4 \mathrm{~h}(41 \%$ vs. $19 \%$; $\mathrm{p}<0.001)$, and superior to placebo for pain-free at $4 \mathrm{~h}(22 \% \mathrm{vs}$. $10 \% ; \mathrm{p}=0.005){ }^{26}$

Although the above trials indicate that for patients responding poorly to a given triptan, another triptan is able to show efficacy superior to placebo, none of the trials included the original triptan in blinded fashion for comparison in the placebocontrolled portion of the trial. It is therefore impossible to determine from this data whether, had the original triptan been included in the trial, the second triptan would have been superior to it. Nevertheless, the data available does suggest, as does clinical experience, that many patients benefit from switching triptans if the response to the first triptan is not optimal.

\section{Early intervention}

There is considerable evidence from prospective, randomized, controlled trials of triptans that early intervention when pain is still mild results in higher pain-free and sustained pain-free rates, and more rapid return to normal functioning. Placebo-controlled early intervention trials have been done with zolmitriptan $(2.5 \mathrm{mg})$, frovatriptan $(2.5 \mathrm{mg})$, sumatriptan (50 and $100 \mathrm{mg}$ ), eletriptan (20 and $40 \mathrm{mg}$ ), sumatriptan fast disintegrating tablets (50 and $100 \mathrm{mg}$ ), and rizatriptan $(10 \mathrm{mg})$ (see Table 6). ${ }^{27-33}$ These early intervention trials generally produced higher 2-h pain-free rates than clinical trials in which the headache was not treated until it had become of moderate or severe intensity. In the early treatment studies, methodologies differed from trial to trial, so that they cannot all be directly compared. However, very high 2 -h pain-free rates were reported for many trials, including: $57 \%$ for zolmitriptan $2.5 \mathrm{mg}$ when patients were treated within 15 minutes of headache onset, $57 \%$ for sumatriptan $100 \mathrm{mg}, 47 \%$ for eletriptan $40 \mathrm{mg}, 59 \%$ for rizatriptan $10 \mathrm{mg}$, and $66 \%$ for the sumatriptan $100 \mathrm{mg}$ fast disintegrating tablet. These 2 -h pain-free rates cannot be directly compared, not only because of differing trial methodologies, but also because the trials had different placebo pain-free rates. Please consult Table 6 for more details.

It is of interest, that early treatment also appears to result in higher 24-h sustained pain-free rates, which were reported for example at $48 \%$ for rizatriptan $10 \mathrm{mg}^{32}$ Whether or not treatment during the migraine aura phase is advisable is discussed in Section 3.

\section{Headache recurrence}

Return of headache within 24 hours after initial treatment success (i.e., recurrence) occurs in approximately one-third of triptan-treated attacks. ${ }^{34}$ In case of headache recurrence, a second dose of triptan may be taken after an appropriate time interval (i.e., $2 \mathrm{~h}$ for most triptans, except $4 \mathrm{~h}$ for frovatriptan and naratriptan; the product monograph limits eletriptan $40 \mathrm{mg}$ to one dose per day in Canada, although in some other countries the $80 \mathrm{mg}$ dose is also available; see Section 3 of guideline).

Clinical data derived from 31 triptan, placebo-controlled efficacy trials used in a previous meta-analysis ${ }^{15}$ concluded that triptans with longer half-lives and greater $5-\mathrm{HT}_{1 \mathrm{~B}}$ receptor potency had the lowest rate of headache recurrence. Mean 
headache recurrence rates were lowest for frovatriptan (17\%), eletriptan $(24 \%)$, and naratriptan $(25 \%) .{ }^{35}$ However, it is problematic to compare recurrence rates among triptans, as a headache can only recur if it responded to the triptan in the first place.

\section{Recommendations (triptans)}

1. Strong recommendation, high quality evidence: Triptans (almotriptan, eletriptan, frovatriptan, naratriptan, rizatriptan, sumatriptan, and zolmitriptan) are recommended for the acute treatment of migraine attacks that are likely to become moderate or severe.

2. Strong recommendation, moderate quality evidence: If a patient does not respond well to one triptan or tolerates it poorly, other triptans should be tried over time in subsequent attacks. It is recommended that patients wait 24 hours before trying another triptan.

3. Strong recommendation, high quality evidence: If migraine response to sumatriptan is inadequate, consider use of naproxen sodium $500 \mathrm{mg}$ to be given simultaneously with the triptan.

4. Strong recommendation, low quality evidence: If migraine response to other triptans (other than sumatriptan) is inadequate, consider the addition of an NSAID (e.g., naproxen sodium) to be given simultaneously with the triptan.

5. Strong recommendation, high quality evidence: Patients with migraine attacks that are usually moderate or severe in intensity should be advised to take triptans early during their migraine attacks while pain is mild (caution the patient regarding medication overuse headache - see Section 3).

\section{Ergot Derivatives}

\section{Overview}

The ergot derivatives are older drugs, and clinical trials are generally of poor quality. There are very few randomized, placebo-controlled trials on efficacy of ergot derivatives in acute migraine treatment. ${ }^{36}$ The ergot derivatives, like the triptans, are vasoconstrictors, and are contraindicated in patients with cardiovascular disease. Because they are less specific than the triptans and affect a greater variety of receptors, they generally have more side effects, such as nausea. The ergot derivatives are divided into dihydroergotamine (DHE), which is available in an injectable and an intranasal formulation, and ergotamine, which is available in oral tablet form only (in combination with caffeine).

\section{a) Dihydroergotamine (DHE)}

\section{Evidence Summary}

Intranasal (IN): The IN formulation of DHE has shown variable to superior efficacy compared with placebo in acute migraine 37,38 ; however, it was less effective than IN or SC sumatriptan. ${ }^{39,40}$ In a multicentre, randomized, double-blind, double-dummy, crossover study ( $\mathrm{n}=368$, treating two attacks), significantly more patients obtained headache relief at 60 minutes after treatment with IN sumatriptan $20 \mathrm{mg}$ (as a single dose in one nostril) than with IN DHE $1 \mathrm{mg}$ (given as one $0.5 \mathrm{mg}$ spray in each nostril plus optional $0.5 \mathrm{mg}$ in each nostril, $30 \mathrm{~min}$ after first dose) (53\% vs. $41 \%$; p <0.001).$^{39}$ In a multicentre, randomized, double-blind, double-dummy, crossover study $(\mathrm{n}=266)$, SC sumatriptan (6 mg) was significantly better than IN DHE (1 mg plus optional $1 \mathrm{mg}$ ) at providing headache relief and resolution of headache at all time points from 15 minutes to 2 hours ( $\mathrm{p}<0.001$ at all time points); SC sumatriptan had a faster onset of action than IN DHE. Headache relief was achieved and maintained for 24 hours in $54 \%$ of sumatriptan-treated patients compared with $39 \%$ of DHE IN-treated patients $(\mathrm{p}<0.001)$. However, more patients reported headache recurrence after treatment with SC sumatriptan $(31 \%)$ than after IN DHE $(17 \%) .^{40}$

Subcutaneous: In a multicentre, randomized, double-blind clinical trial $(\mathrm{n}=295)$, headache relief with SC DHE (1 mg) was similar to that of SC sumatriptan $6 \mathrm{mg}(85.5 \%$ vs. $83.3 \%$ by 4 hours, respectively); DHE had a slower onset of action but fewer headache recurrences compared with sumatriptan $(17.7 \%$ vs. $45 \%$, respectively; $\mathrm{p} \leq 0.001) .{ }^{41}$

\section{Recommendation (dihydroergotamine)}

1. Weak recommendation, moderate quality evidence: Dihydroergotamine (intranasal or subcutaneous selfinjection) may be considered for the acute treatment of moderate or severe migraine attacks.

\section{b) Ergotamine}

\section{Overview}

Ergotamine use is problematic in migraine because of poor oral absorption, vasoconstrictive side effects, and the frequent occurrence of dose limiting side effects such as nausea, which make it difficult to achieve a therapeutic dose in many patients. However, the cost of ergotamine is much lower than that of triptans, and it may be an option in selected patients who do not respond to triptans or are unable to pay for triptans.

\section{Evidence Summary (comparative studies with triptans)}

In a multicentre, randomized, double-blind, double-dummy, parallel-group trial $(n=580)$, oral ergotamine (2 mg plus caffeine $200 \mathrm{mg}$ ) was inferior to oral sumatriptan (100 mg dispersible tablet) for $2 \mathrm{~h}$ headache relief (48\% vs. 66\%, respectively; $\mathrm{p}<0.001)$ and $2 \mathrm{~h}$ pain-free $(13 \%$ vs. $35 \%$, respectively; $\mathrm{p}<0.001) .{ }^{42}$ However, $41 \%$ of patients in the sumatriptan group had headache recurrence within 48 hours compared with $30 \%$ in the ergotamine/caffeine group $(\mathrm{p}=0.009)$. In another multicentre, randomized, placebo-controlled, double-blind trial, parallelgroup study $(\mathrm{n}=733)$, oral ergotamine $(2 \mathrm{mg}$ plus caffeine $200 \mathrm{mg}$ ) was inferior to oral eletriptan $40 \mathrm{mg}$ and $80 \mathrm{mg}$ for 2-h headache response ( $33 \%$ vs. $54 \%$ for eletriptan $40 \mathrm{mg} ; \mathrm{p}<0.001$ ) and 2 -h pain-free (10\% vs. $28 \%$ for eletriptan $40 \mathrm{mg}$ vs. $5 \%$ for placebo; $\mathrm{p}<0.001) .{ }^{43}$ In a third trial, almotriptan was more effective than caffeine/ergotamine, with significantly more patients becoming pain-free at $2 \mathrm{~h}$ post-dose $(21 \%$ vs. $14 \%$, respectively; $\mathrm{p}<0.05)$; 2-h pain-relief rate was $58 \%$ vs. $45 \%$, respectively $(\mathrm{p}<0.01){ }^{44}$

A meta-analysis of oral sumatriptan concluded that ergotamine (plus caffeine) was significantly less effective than oral sumatriptan. ${ }^{45}$ 


\section{Recommendations (ergotamine)}

1. Strong recommendation, moderate quality evidence: Ergotamine should not be used routinely for acute migraine attacks, due to inferior efficacy compared to the triptans, and the potential for more side effects.

2. Weak recommendation, moderate quality evidence: Ergotamine may be considered for use in some patients, for example when triptans are not available to the patient or not effective.

\section{NON-SPECIFIC AGENTS}

\section{Simple Analgesics and NSAIDs}

\section{Overview}

Over-the-counter (OTC) analgesics are used exclusively for migraine attacks by about $60 \%$ of patients. However, most trials of OTC medications have systematically excluded patients with severe disability (e.g., requiring bed rest) during $50 \%$ or more of attacks, or vomiting with more than $20 \%$ of attacks. When data from 11 adequately designed trials were combined in a systematic review (in 2003), OTC analgesics [e.g., acetaminophen (alone or in combination with caffeine), ASA (alone or in combination with either caffeine and/or acetaminophen), ibuprofen] were more effective than placebo for headache relief within $2 \mathrm{~h}$, and a significant minority of patients achieved pain-free status within $2 \mathrm{~h}$. Up to $76 \%$ of patients returned to normal functioning, particularly if their symptoms and disability were mild to moderate. The authors concluded that OTC medications are only indicated in patients with mild to moderate migraine symptoms, and patients who experience disability during most attacks and/or vomiting in more than $20 \%$ of attacks are poor candidates for OTC-exclusive therapy. ${ }^{46}$

Various NSAIDs including ibuprofen, naproxen sodium, diclofenac potassium, and others have been studied in acute migraine. There appear to be no significant differences in efficacy among the various NSAIDS; however, there is a lack of head-to-head comparisons. NSAIDs appear to be effective for mild to moderate attacks (and perhaps in severe attacks in some patients); however, they are associated with a risk for gastrointestinal adverse effects, including bleeding. NSAIDs should be avoided in patients with peptic ulceration, history of gastrointestinal bleed, or ASA-induced asthma. Trials with rofecoxib, a COX-2 inhibitor, have also demonstrated efficacy in migraine ${ }^{47,48}$; however, rofecoxib is no longer available on the market, due to a risk of cardiovascular adverse effects.

\section{a) Acetylsalicylic Acid (ASA)}

\section{Evidence Summary}

\section{ASA with or without Metoclopramide (see Table 7)}

A Cochrane systematic review (2010) of 13 trials comparing ASA (900 or 1,000 mg) alone (pain-free at 2 h: $24 \%$ vs. $11 \%$ for placebo; $\mathrm{NNT}=8.1)$ or in combination with metoclopramide (10 mg) (pain-free at $2 \mathrm{~h}: 18 \%$ vs. $7 \%$ for placebo; NNT=8.8), with placebo or other active comparators (mainly sumatriptan 50 or $100 \mathrm{mg}$ ) concluded that ASA $1,000 \mathrm{mg}$ is an effective treatment for acute migraine in adults, with efficacy similar to that of sumatriptan $50 \mathrm{mg}$ or $100 \mathrm{mg}$; the addition of metoclopramide $10 \mathrm{mg}$ improved relief of nausea and vomiting.
Sumatriptan $100 \mathrm{mg}$ was superior to ASA (900 mg) plusmetoclopramide (10 mg) for pain-free at $2 \mathrm{~h}(28 \% \mathrm{vs} .18 \%$, respectively; relative benefit of ASA + metoclopramide vs. sumatriptan was 0.63 , giving an NNT of 9.8). Adverse effects were mainly mild and transient, were slightly more common with ASA than placebo, but less common than with sumatriptan $100 \mathrm{mg}$. However, further head-to-head studies are needed to establish the efficacy of ASA compared to other triptans and NSAIDs. ${ }^{49}$

\section{Effervescent ASA (see Table 7)}

An individual patient data meta-analysis (2007) of three randomized, controlled trials of effervescent ASA (eASA) concluded that eASA $1,000 \mathrm{mg}$ is as effective as sumatriptan $50 \mathrm{mg}$ (pain-free at $2 \mathrm{~h}: 27.1 \%$ vs. $29 \%$, respectively, vs. $15.1 \%$ for placebo) for the treatment of acute migraine attacks (including severe attacks), and has a better side effect profile. ${ }^{50}$

\section{Recommendation (ASA)}

1. Strong recommendation, high quality evidence: ASA (975-1,000 mg tablets or effervescent formulation), given with oral metoclopramide $(10 \mathrm{mg})$ if nausea is present, is recommended for the acute treatment of migraine attacks of all severities.

\section{b) Ibuprofen}

\section{Evidence Summary (see Table 7)}

A systematic review/meta-analysis (2007) of five trials of low-dose ibuprofen concluded that ibuprofen (200 and $400 \mathrm{mg}$ ) is effective in reducing headache intensity and rendering adult patients pain-free at $2 \mathrm{~h}$ compared to placebo (NNT for pain-free at $2 \mathrm{~h}=13$ for $200 \mathrm{mg}$, and $=9$ for $400 \mathrm{mg}$ ); photophobia and phonophobia improved with the $400 \mathrm{mg}$ dose only. Adverse effects were similar for ibuprofen and placebo. ${ }^{51}$

A Cochrane systematic review (2010) determined the efficacy and tolerability of ibuprofen alone or in combination with an antiemetic, compared to placebo and other active interventions in the treatment of acute migraine headaches in adults. ${ }^{52}$ Nine studies (4273 participants, 5223 attacks) fulfilled entry criteria, and were included in the analysis; none of the studies combined ibuprofen with a self-administered antiemetic. All studies utilized single doses of medication. For ibuprofen $400 \mathrm{mg}$ versus placebo, NNTs for 2-h pain-free (26\% vs. $12 \%$, respectively), 2$\mathrm{h}$ headache relief (57\% vs. $25 \%$ respectively), and 24 -h sustained headache relief ( $45 \%$ vs. $19 \%$, respectively) were $7.2,3.2$ and 4.0 , respectively. For ibuprofen $200 \mathrm{mg}$ versus placebo, NNTs for 2-h pain-free (20\% vs. $10 \%$, respectively) and 2-h headache relief (52\% vs. 37\%, respectively) were 9.7 and 6.3, respectively. The $400 \mathrm{mg}$ dose was significantly better for 2-h headache relief than $200 \mathrm{mg}$. Solubilized formulations of ibuprofen $400 \mathrm{mg}$ (e.g., liquid containing capsules ${ }^{53}$ ) were significantly superior to standard tablets for 1-h (but not 2-h) headache relief (NNT=3.9 for solubilized formulations vs. NNT=8.3 for regular tablets for 1 -h headache response; $\mathrm{p}=0.0114$ ). However, there are no studies directly comparing solubilized formulations with standard formulations. The Cochrane review concluded that ibuprofen is an effective treatment for acute migraine headache, providing pain relief in about half of sufferers; however, it only provided 
complete relief from pain (approximately 1 in 4 patients taking ibuprofen $400 \mathrm{mg}$ ) and associated symptoms in a minority of sufferers. For all efficacy outcomes, NNTs were better with $400 \mathrm{mg}$ than $200 \mathrm{mg}$ (compared to placebo) but the $400 \mathrm{mg}$ dose achieved statistical significance only for headache relief at $2 \mathrm{~h}$. Soluble formulations provided more rapid relief. Adverse effects with ibuprofen were generally mild and transient.

In a randomized, placebo-controlled trial comparing ibuprofen $(400 \mathrm{mg})$ with rizatriptan $(10 \mathrm{mg})$, rizatriptan was superior in 2 -h headache relief $(73 \%$ vs. $53.8 \%$; $\mathrm{p}=0.0001)$ and in use of rescue medication, but not for 2-h pain-free and 24-h headache relapse..$^{54}$

\section{Recommendation (ibuprofen)}

1. Strong recommendation, high quality evidence: Ibuprofen [400 mg tablet or solubilized (liquid containing capsules) formulation] is recommended for the acute treatment of migraine attacks of all severities.

2. Strong recommendation, moderate quality evidence: Ibuprofen (400 mg) in solubilized formulation (liquid containing capsules) is recommended for the acute treatment of migraine attacks of all severities for patients desiring a faster onset of therapeutic effect as compared to the regular ibuprofen tablets.

\section{c) Naproxen Sodium}

\section{Evidence Summary (see Table 7)}

A systematic review/meta-analysis (2010) of four trials (one paper reported results of two trials, and was treated as two separate trials) of naproxen sodium concluded that it was more effective than placebo in reducing pain intensity and providing pain-free within $2 \mathrm{~h}$ in adults with moderate or severe migraine attacks [pooled risk ratio for headache relief at $2 \mathrm{~h}=1.58$ $(\mathrm{p}<0.00001)$, and pain-free at $2 \mathrm{~h}=2.22(\mathrm{p}=0.0002)] .{ }^{55}$ Three of the studies used $500 \mathrm{mg}$ doses of naproxen sodium, and one study used $825 \mathrm{mg}$. Pain-free at $2 \mathrm{~h}$ was relatively better with naproxen sodium $825 \mathrm{mg}$ than $500 \mathrm{mg}$ (RR 4.26, 95\% CI 1.969.27 vs. RR $1.83,95 \%$ CI 1.42-2.36), as well as sustained painfree response (RR 4.44, 95\% CI 1.91-10.32 vs. RR 1.55, 95\% CI 1.15-2.09). In Europe, $825 \mathrm{mg}$ is the highest recommended dose for acute migraine, whereas lower doses are generally recommended in North America (i.e., 275-550 mg). There was no significant difference in headache recurrence rate between naproxen sodium and placebo. Naproxen sodium generally relieved nausea, photophobia, and phonophobia significantly better than placebo. Adverse events commonly associated with naproxen sodium were nausea, dizziness, dyspepsia, and abdominal pain. The efficacy of naproxen sodium relative to other acute therapies requires head-to-head clinical trials. Naproxen sodium is preferred over naproxen (base) for acute migraine due to its faster onset of action. However, controlled release formulations of naproxen sodium would not be appropriate for acute migraine treatment.

\section{Recommendation (naproxen sodium)}

1. Strong recommendation, high quality evidence: Naproxen sodium in immediate release formulation (500 or $550 \mathrm{mg}$; up to $825 \mathrm{mg}$, if needed and tolerated) is recommended for the acute treatment of migraine attacks of all severities.

\section{d) Diclofenac Potassium}

\section{Overview}

Diclofenac sodium is available in Canada only as an entericcoated or extended-release tablet with a prolonged release of active drug, and is indicated for chronic pain. Because of a slow onset of action, these preparations would not be suitable for the acute treatment of migraine attacks in most patients. ${ }^{56}$ Diclofenac potassium is available as an immediate-release tablet, providing a rapid onset of action for the treatment of acute pain conditions. Diclofenac potassium for oral solution, a novel, water-soluble buffered powder formulation, has been available in other countries, and has been recently been approved for use in Canada specifically for the acute treatment of migraine attacks in adults. It has a time to maximum plasma concentration $\left(\mathrm{T}_{\max }\right)$ of approximately 15 minutes, suggesting the potential for a rapid onset of effect. .7,58 $^{5}$

\section{Evidence Summary}

A Cochrane systematic review (2012) included five studies in adults $(n=1356)$ comparing oral diclofenac potassium with placebo, and also with sumatriptan in one study (none of the studies combined diclofenac with an antiemetic). ${ }^{59}$ The review concluded that based on limited data, oral diclofenac potassium $50 \mathrm{mg}$ is an effective treatment for acute migraine, reducing moderate to severe pain to no more than mild pain (headache relief) in about $55 \%(\mathrm{NNT}=6.2)$ of those treated, to no pain (pain-free) at $2 \mathrm{~h}$ in approximately $22 \%(\mathrm{NNT}=8.9)$, and to no pain sustained to $24 \mathrm{~h}$ (pain-free at $24 \mathrm{~h}$ ) in approximately $19 \%$ $(\mathrm{NNT}=9.5)$. There were insufficient data to evaluate other doses of oral diclofenac (e.g., $100 \mathrm{mg}$ ), or to compare different formulations or different dosing regimens. Adverse effects of diclofenac potassium were mostly mild to moderate intensity and self-limiting, and were not significantly different from placebo over the short term. Only one study compared oral diclofenac with an active comparator (oral sumatriptan $100 \mathrm{mg}$ ). ${ }^{60}$ This study used a primary efficacy criterion of migraine headache pain recorded on a $100 \mathrm{~mm}$ visual analog scale (VAS) $2 \mathrm{~h}$ after dosing. Diclofenac potassium was more effective than placebo in reducing headache pain at $2 \mathrm{~h}(\mathrm{p}<0.001 ; 50 \mathrm{mg}$ and $100 \mathrm{mg}$ doses had similar efficacy); no statistically significant difference was found between either dose of diclofenac potassium and sumatriptan $100 \mathrm{mg}$. Both doses of diclofenac potassium were significantly better than placebo and sumatriptan in reducing nausea at $2 \mathrm{~h}$. Further head-to-head trials are needed to establish the place in therapy for diclofenac potassium relative to alternative acute treatments for migraine.

A multicentre (Europe), randomized, controlled, doubleblind, double-dummy, cross-over trial compared single doses of diclofenac potassium $50 \mathrm{mg}$ sachets (powdered formulation for oral solution) and $50 \mathrm{mg}$ tablets with placebo in 328 patients with migraine pain (888 attacks). ${ }^{61}$ For the primary endpoint (painfree at $2 \mathrm{~h}$ ), $24.7 \%$ of patients were pain-free at $2 \mathrm{~h}$ post-dose with diclofenac sachets, $18.5 \%$ with diclofenac tablets, and $11.7 \%$ with placebo. Treatment differences were significant for sachets vs. placebo $(\mathrm{p}<0.0001)$, tablets vs. placebo $(\mathrm{p}=0.004)$, 
Table 4: Triptans - Randomized, double-blind, comparative trials versus other triptans* [part 1] ${ }^{89-103}$

\begin{tabular}{|c|c|c|c|}
\hline $\begin{array}{l}\text { Drugs, doses, dosage } \\
\text { form }\end{array}$ & $\begin{array}{l}\text { Study design, \# pts included in } \\
\text { analysis (n), primary endpoints }\end{array}$ & Results (primary endpoints) & Conclusions/comments \\
\hline $\begin{array}{l}\text { Zolmitriptan } 2.5 / 5 \\
\text { mg vs. sumatriptan } \\
25 / 50 \mathrm{mg} \text {; oral } \\
\text { tablets }^{89}\end{array}$ & $\begin{array}{l}\text { PG, MC; up to } 6 \text { attacks treated over } 6 \\
\text { months; } n=1212 \text { (treated at least } 2 \\
\text { attacks) } \\
\text { 2-h headache response** }\end{array}$ & $\begin{array}{l}\text { 2-h headache response: } \\
\text { Z-2.5 mg: } 67.1 \% \text {; Z-5 mg: } 64.8 \% \text { S-25 mg: } 59.6 \% \text {; S-50 } \\
\text { mg: } 63.8 \% \\
\text { Z-2.5 mg significantly more effective vs. S- } 25 / 50 \mathrm{mg} \\
(p<0.001) ; \mathrm{Z}-5 \mathrm{mg} \text { significantly more effective vs. S-25 } \\
\text { mg }(p<0.001)\end{array}$ & $\begin{array}{l}\text { Z- } 2.5 / 5 \mathrm{mg} \text { at least as effective as S- } 25 / 50 \mathrm{mg} \text { for all } \\
\text { parameters studied; } \mathrm{Z}-2.5 \mathrm{mg} \text { significantly more } \\
\text { effective vs. S- } 50 \mathrm{mg} \text { for } 2 \mathrm{~h} \& 4 \mathrm{~h} \text { headache } \\
\text { response; } \mathrm{Z}-2.5 / 5 \mathrm{mg} \text { significantly more likely to } \\
\text { have pain relief over } 24 \mathrm{~h} \text { vs. S } \\
\text { (Note: } \mathrm{Z}-5 \mathrm{mg} \text { is not available in Canada) }\end{array}$ \\
\hline $\begin{array}{l}\text { Zolmitriptan } 2.5 / 5 \mathrm{mg} \\
\text { vs. sumatriptan } 50 \\
\mathrm{mg} \text {; oral tablets }\end{array}$ & $\begin{array}{l}\text { PG, DD, MC; } 1: 1: 1 \text { ratio; up to } 6 \\
\text { attacks treated; } \mathrm{n}=1522 \text { (treated at least } \\
2 \text { attacks) } \\
\text { 2-h headache response** }\end{array}$ & $\begin{array}{l}\text { 2-h headache response: } \\
\text { Z-2.5 mg: } 62.9 \% \text {; Z-5 mg: } 65.7 \% \text {; S-50 mg: } 66.6 \% \text { (NS } \\
\text { difference between Z-2.5/5mg vs. S-50 mg) }\end{array}$ & $\begin{array}{l}\text { Similar efficacy for Z-2.5/5 mg vs. S- } 50 \mathrm{mg} \text {; similar } \\
\text { rates of meaningful migraine relief }(1,2, \text { or } 4 \mathrm{~h}) \& \\
\text { sustained }(24 \mathrm{~h}) \text { pain relief } \\
\text { (Note: } \mathrm{Z}-5 \mathrm{mg} \text { is not available in Canada) }\end{array}$ \\
\hline $\begin{array}{l}\text { Rizatriptan } 10 \mathrm{mg} \text { vs. } \\
\text { naratriptan } 2.5 \mathrm{mg} \text {; } \\
\text { oral tablets }^{91}\end{array}$ & $\begin{array}{l}\text { PC, MC, single attack; } n=522 \\
\text { Time to headache relief within } 2 \mathrm{~h}^{*}\end{array}$ & $\begin{array}{l}\text { Time to headache relief within } 2 \mathrm{~h}: \mathrm{R} \text { superior to } \mathrm{N} \\
\text { (hazard ratio } 1.62, p<0.001 \text { ) }\end{array}$ & $\begin{array}{l}\mathrm{R} \text { more effective than } \mathrm{N} \& \text { provided earlier headache } \\
\text { relief than } \mathrm{N} \text {; more patients pain-free at } 2 \mathrm{~h} \text { with } \mathrm{R} \\
\text { vs. } \mathrm{N}(44.8 \% \text { vs. } 20.7 \%, p<0.001) \text {; earlier relief of } \\
\text { associated symptoms \& return to normal function in } \\
2 \mathrm{~h} \text { with R vs. } \mathrm{N}(p<0.001) \text {; similar overall pain } \\
\text { relief over } 24 \mathrm{~h} \text { for R \& } \mathrm{N}\end{array}$ \\
\hline $\begin{array}{l}\text { Rizatriptan } 10 / 20 / 40 \\
\text { mg vs. sumatriptan } \\
100 \mathrm{mg} \text {; oral tablets }\end{array}$ & $\begin{array}{l}\text { PC, PG, MC, dose-ranging study; } \\
\mathrm{n}=449 \\
\text { 2-h headache response }{ }^{* *}\end{array}$ & $\begin{array}{l}\text { 2-h headache response: } \\
\text { S-100 mg: } 46 \% \text {; R-10 mg: } 52 \% \text {; R-20 mg: } 56 \% \text {; R-40 mg: } \\
\text { 67\%; P: } 18 \% \text {; R-40 mg significantly better vs. S-100 mg; } \\
\text { R-10/20 mg similar to S-100 mg }\end{array}$ & $\begin{array}{l}\text { Efficacy of R-10/20 mg comparable to } \mathrm{S}-100 \mathrm{mg} \text {; R- } \\
40 \mathrm{mg} \text { superior to } \mathrm{S}-100 \mathrm{mg} \text { but high frequency of } \\
\text { ADRs with R- } 40 \mathrm{mg} \\
\text { (Note: } \mathrm{R}-20 / 40 \mathrm{mg} \text { not available in Canada) }\end{array}$ \\
\hline $\begin{array}{l}\text { Rizatriptan } 5 / 10 \mathrm{mg} \\
\text { vs. sumatriptan } 25 / 50 \\
\text { mg; oral tablets }\end{array}$ & $\begin{array}{l}\mathrm{PC}, \mathrm{CO}, \mathrm{MC}, 2 \text { attack trial, } 5 \text { sequence } \\
\text { groups; active vs. placebo ratio } 2: 1 ; \\
\mathrm{n}=1329 \text { (treated at least one attack) } \\
\text { Time to pain relief within } 2 \mathrm{~h}^{* *}\end{array}$ & $\begin{array}{l}\text { Time to pain relief within } 2 \mathrm{~h} \text { : } \\
\mathrm{R} \text { superior to } \mathrm{S} ; \mathrm{R}-10 \mathrm{mg} \text { vs. } \mathrm{S}-50 \mathrm{mg} \text { : hazard ratio } 1.14 \\
(p<0.05)\end{array}$ & $\begin{array}{l}\text { R-5/10 mg provided faster relief of headache pain \& } \\
\text { greater relief of migraine symptoms (esp. nausea) } \\
\text { than S-25/50 mg; response to R better on other } \\
\text { measures (e.g., functional disability, satisfaction) }\end{array}$ \\
\hline $\begin{array}{l}\text { Rizatriptan } 5 / 10 \mathrm{mg} \\
\text { vs. sumatriptan } 100 \\
\mathrm{mg} \text {; oral tablets }\end{array}$ & $\begin{array}{l}\text { PC, PG, TD, MC, single-dose study; } \\
\mathrm{n}=1091 \\
\text { Time to pain relief within } 2 \mathrm{~h} * * \text { for R- } \\
10 \mathrm{mg} \text { vs. S- } 100 \mathrm{mg}\end{array}$ & $\begin{array}{l}\text { Time to pain relief within } 2 \mathrm{~h} \text { : } \\
\mathrm{R}-10 \mathrm{mg} \text { had earlier onset than } \mathrm{S}-100 \mathrm{mg}[p=0.032 ; \\
\text { hazard ratio } 1.21 \text { after age-adjusted analysis (since pts in } \\
\mathrm{R} \text { group were younger vs. S group)] }\end{array}$ & $\begin{array}{l}\mathrm{R}-10 \mathrm{mg} \text { has faster onset than } \mathrm{S}-100 \mathrm{mg} ; \mathrm{R}-10 \mathrm{mg} \\
\text { superior to } \mathrm{S}-100 \mathrm{mg} \text { for pain-free response } \\
(p=0.032), \text { reduction in functional disability } \\
(\mathrm{p}=0.015) \& \text { relief of nausea }(\mathrm{p}=0.010) \text { at } 2 \mathrm{~h} ; \\
\text { significantly fewer AEs with R-10 mg vs. } \mathrm{S}-100 \mathrm{mg} \\
(33 \% \text { vs. } 41 \%, p=0.014)\end{array}$ \\
\hline $\begin{array}{l}\text { Rizatriptan } 5 / 10 \mathrm{mg} \\
\text { vs. sumatriptan } 25 / 50 \\
\text { mg; oral tablets }\end{array}$ & $\begin{array}{l}\text { PC, 2-attack, CO, } 6 \text { treatment } \\
\text { sequences; } \mathrm{n}=1447 \text { (treated at least one } \\
\text { attack) Time to pain relief within } 2 \mathrm{~h}^{* *}\end{array}$ & $\begin{array}{l}\text { Time to pain relief within } 2 \mathrm{~h} \text { : } \\
\mathrm{R}-10 \mathrm{mg} \text { vs. S-50 } \mathrm{mg}(\mathrm{NS}) \text {; } \\
\mathrm{R}-5 \mathrm{mg} \text { superior to } \mathrm{S}-25 \mathrm{mg} \text { (OR } 1.22 ; p=0.007)\end{array}$ & $\begin{array}{l}\text { Faster onset of pain relief (at } 1 \mathrm{~h} \text { ) with R-10 mg vs. } \\
\text { S- } 50 \mathrm{mg} \text { (but no difference at } 2 \mathrm{~h} \text { ); secondary } \\
\text { endpoints favoured R over S }\end{array}$ \\
\hline $\begin{array}{l}\text { Almotriptan } 12.5 \mathrm{mg} \\
\text { vs. sumatriptan } 50 \\
\text { mg; oral tablets } \\
\text { (encapsulated) }^{96}\end{array}$ & $\begin{array}{l}\text { PC, } P G, M C, \text { single-dose; } n=1173 \\
\text { 2-h headache relief** }\end{array}$ & $\begin{array}{l}\text { 2-h headache relief: } \\
\text { A: } 58 \%, \text { S: } 57.3 \% \text { (NS) } \\
\text { Headache freedom (i.e., pain-free) at } 2 \mathrm{~h} \text { (secondary): } \\
\text { A: } 17.9 \%, \text { S: } 24.6 \%(p=0.005)\end{array}$ & $\begin{array}{l}\text { Study compared optimum doses of both drugs; } \\
\text { similar efficacy; less chest pain with A vs. S }\end{array}$ \\
\hline $\begin{array}{l}\text { Eletriptan } 40 \mathrm{mg} \text { vs. } \\
\text { sumatriptan } 100 \mathrm{mg} \text {; } \\
\text { oral tablets } \\
\text { (encapsulated) }^{97}\end{array}$ & $\begin{array}{l}\text { PG, DD, MC, single attack, 1:2:1 ratio; } \\
\mathrm{n}=2072 \\
\text { 2-h headache relief** }\end{array}$ & $\begin{array}{l}\text { 2-h headache relief: } \\
\text { E: } 67 \%, \mathrm{~S}: 59 \%(\mathrm{p}<0.01) \\
\text { 2-h pain-free }(\text { secondary): } \\
\text { E: } 36 \%, \mathrm{~S}: 27 \%(p<0.0001)\end{array}$ & $\begin{array}{l}\text { Greater efficacy for E vs. S (primary and secondary } \\
\text { endpoints); E: rapid headache response }(1 \mathrm{~h}) \& \\
\text { better sustained response }(24 \mathrm{~h}) \text { vs. S }\end{array}$ \\
\hline $\begin{array}{l}\text { Eletriptan } 40 / 80 \mathrm{mg} \\
\text { vs. sumatriptan } \\
\text { 50/100 mg; oral } \\
\text { tablets } \\
{\text { (encapsulated })^{98}}\end{array}$ & $\begin{array}{l}\text { PC, DD, PG, MC, multiple attack; } \\
\mathrm{n}=774 \\
\text { 1-h headache response }{ }^{* *} \text { (first attack) }\end{array}$ & $\begin{array}{l}\text { 1-h headache response: } \\
\text { E-80 mg: } 37 \% \text { vs. S-50 mg: } 24 \%(p<0.05) \\
\text { E-40 mg: } 30 \% \text { (superior to P) } \\
\text { S-100 mg: } 27 \% \text { vs. E- } 80 \mathrm{mg}: 37 \% \text { (NS) }\end{array}$ & $\begin{array}{l}\text { E- } 80 \mathrm{mg} \text { significantly better vs. S- } 50 \mathrm{mg} \text { (but similar } \\
\text { to } \mathrm{S}-100 \mathrm{mg} \text { ) for } 1 \mathrm{~h} \text { headache response; E- } 80 \mathrm{mg} \\
\text { significantly superior consistency of response across } \\
\text { multiple attacks vs. S- } 50 / 100 \mathrm{mg} \\
\text { (Note: } \mathrm{E}-80 \mathrm{mg} \text { is not an approved dose in Canada) }\end{array}$ \\
\hline $\begin{array}{l}\text { Almotriptan } 12.5 \mathrm{mg} \\
\text { vs. zolmitriptan } 2.5 \\
\mathrm{mg} ; \text { oral tablets } \\
\text { (encapsulated) }^{99}\end{array}$ & $\begin{array}{l}\text { DB, PG, MC, (not PC), single attack; } \\
n=1103 \\
\text { Composite endpoint: sustained pain- } \\
\text { free + no adverse events (SNAE) }\end{array}$ & $\begin{array}{l}\text { No significant difference in SNAE (A: } 29.2 \% \text { vs. Z: } \\
31.8 \% \text { ) } \\
\text { Significantly lower incidence of triptan-associated AEs } \\
\text { for A group vs. Z group }\end{array}$ & $\begin{array}{l}\text { A \& } \mathrm{Z} \text { associated with similar efficacy \& overall } \\
\text { tolerability; A associated with significantly lower } \\
\text { rate of triptan-associated AEs }\end{array}$ \\
\hline $\begin{array}{l}\text { Eletriptan } 80 \mathrm{mg}(\& \\
40 \mathrm{mg}) \text { vs. } \\
\text { zolmitriptan } 2.5 \\
\mathrm{mg}^{100} ; \text { oral tablets }\end{array}$ & $\begin{array}{l}\mathrm{DB}, \mathrm{DD}, \mathrm{PC}, \mathrm{PG}, \mathrm{MC}, \text { single attack; } \\
\mathrm{n}=1312 \\
\text { 2-h headache response }{ }^{* *}\end{array}$ & $\begin{array}{l}\text { 2-h headache response: } \\
\text { E- } 80 \mathrm{mg}: 74 \% \text {; E- } 40 \mathrm{mg}: 64 \% \text {; } \mathrm{Z}-2.5 \mathrm{mg}: 60 \%(p<0.0001 \\
\text { vs. E- } 80 \mathrm{mg}) \text {, and } 22 \% \text { for } \mathrm{P}(p<0.0001 \mathrm{vs} \text {. all active } \\
\text { treatments) }\end{array}$ & $\begin{array}{l}\text { E-80 mg significantly better than Z-2.5 mg; E- } 40 \mathrm{mg} \\
\text { similar efficacy to Z- } 2.5 \mathrm{mg} \text { (secondary endpoint) } \\
\text { AEs more frequent with E- } 80 \mathrm{mg} \\
\text { (Note: E- } 80 \mathrm{mg} \text { is not an approved dose in Canada) }\end{array}$ \\
\hline
\end{tabular}

and for sachets vs. tablets $(\mathrm{p}=0.0035)$. The NNTs compared with placebo to achieve pain-free at $2 \mathrm{~h}$ were 7.75 (95\% CI 5.46 , 13.35) for sachets, and 15.83 (95\% CI 8.63, 96.20) for tablets. Sachets were also superior to tablets for sustained headache response, sustained pain-free, and reduction in headache intensity within the first $2 \mathrm{~h}$ post-dose (measured on visual analog scale) $(\mathrm{p}<0.05)$. The onset of analgesic effect was 15 minutes for sachet versus 60 minutes for tablets.

In the IMPACT study, the efficacy of diclofenac potassium $50 \mathrm{mg}$ for oral solution (dissolved in approximately two ounces of water) was assessed in a multicentre (U.S.), randomized, double-blind, double-dummy, placebo-controlled, parallelgroup, single-attack trial in adult sufferers with migraine (moderate or severe attacks) ${ }^{58}$ Subjects with vomiting in $20 \%$ of migraine attacks or who required bed rest during attacks were excluded. There were four co-primary endpoints. Compared to placebo $(n=347)$, significantly more subjects treated with diclofenac potassium for oral solution $(n=343)$ achieved a $2-h$ pain-free response $(25 \%$ vs. $10 \%$ for placebo; $\mathrm{p}<0.001)$, no nausea ( $65 \%$ vs. $53 \%$; $\mathrm{p}=0.002)$, no photophobia $(41 \%$ vs. $27 \%$; 
Table 4: Triptans - Randomized, double-blind, comparative trials versus other triptans* [part 2] continued

\begin{tabular}{|c|c|c|c|}
\hline $\begin{array}{l}\text { Frovatriptan } 2.5 \mathrm{mg} \\
\text { vs. rizatriptan } 10 \\
\mathrm{mg}^{101} \text {; oral tablets }\end{array}$ & $\begin{array}{l}\mathrm{DB}, \mathrm{MC}, \mathrm{CO} ; 1-3 \text { attacks; each } \\
\text { treatment period not }>3 \text { months } \\
\mathrm{n}=125(\mathrm{ITT}) \\
\text { 2-h pain-free }(\mathrm{PF}) \\
\text { 2-h pain relief }(\mathrm{PR}) * * \\
\text { 48-h SPF*** }\end{array}$ & $\begin{array}{l}\text { Primary (preference to one treatment via questionnaire } \\
\text { with score } 0-5) \text { : NS difference ( } 2.9 \text { for F vs. } 3.2 \text { for R) } \\
\text { Secondary (F vs. R): } \\
\text { 2-h pain-free: } 33 \% \text { vs. } 39 \% \text { (NS) } \\
\text { 2-h pain relief: } 55 \% \text { vs. } 62 \% \text { (NS) } \\
\text { Recurrent episodes within } 48 \text { h: } 21 \% \text { vs. } 43 \%(p<0.001) \\
\text { SPF at } 48 \text { h: } 26 \% \text { vs. } 22 \% \text { (NS) AEs: NS difference }\end{array}$ & $\begin{array}{l}\text { Frovatriptan } 2.5 \mathrm{mg} \text { has similar efficacy vs. } \\
\text { rizatriptan } 10 \mathrm{mg} \text {, but has a significantly lower rate } \\
\text { of recurrent episodes within } 48 \mathrm{~h} \text {; both are similarly } \\
\text { preferred by patients }\end{array}$ \\
\hline $\begin{array}{l}\text { Frovatriptan } 2.5 \mathrm{mg} \\
\text { vs. zolmitriptan } 2.5 \\
\mathrm{mg}^{102} \text {; oral tablets }\end{array}$ & $\begin{array}{l}\mathrm{DB}, \mathrm{MC}, \mathrm{CO} ; 1-3 \text { attacks; each } \\
\text { treatment period not }>3 \text { months } \\
\mathrm{n}=107 \text { (ITT) } \\
\text { 2-h pain-free }(\mathrm{PF}) \\
\text { 2-h pain relief }(\mathrm{PR}) * * \\
\text { 48-h SPF*** }\end{array}$ & $\begin{array}{l}\text { Primary (preference to one treatment via questionnaire } \\
\text { with score } 0-5) \text { : NS difference ( } 2.9 \text { for F vs. } 3.0 \text { for Z) } \\
\text { Secondary (F vs. Z): } \\
\text { 2-h pain-free: } 26 \% \text { vs. } 31 \% \text { (NS) } \\
\text { 2-h pain relief: } 57 \% \text { vs. } 58 \% \text { (NS) } \\
\text { Recurrence rate within } 48 \mathrm{~h}: 21 \% \text { vs. } 24 \% \text { (NS) } \\
\text { SPF at } 48 \mathrm{~h}: 18 \% \text { vs. } 22 \% \text { (NS) AEs: less for F }(p<0.05)\end{array}$ & $\begin{array}{l}\text { Frovatriptan } 2.5 \mathrm{mg} \text { has similar efficacy vs. } \\
\text { zolmitriptan } 2.5 \mathrm{mg} \text {, with some advantages in terms } \\
\text { of tolerability and recurrence; both are similarly } \\
\text { preferred by patients }\end{array}$ \\
\hline $\begin{array}{l}\text { Frovatriptan } 2.5 \mathrm{mg} \\
\text { vs. almotriptan } 12.5 \\
\mathrm{mg}^{103} \text {; oral tablets }\end{array}$ & $\begin{array}{l}\text { DB, MC, CO; } 1-3 \text { attacks; each } \\
\text { treatment period not }>3 \text { months } \\
\mathrm{n}=114 \text { (ITT) } \\
\text { 2-h pain-free }(\mathrm{PF}) \\
\text { 2-h pain relief }(\mathrm{PR}) * * \\
\text { 48-h SPF*** }\end{array}$ & $\begin{array}{l}\text { Primary (preference to one treatment via questionnaire } \\
\text { with score } 0-5 \text { ): NS difference ( } 3.1 \text { for F vs. } 3.4 \text { for A) } \\
\text { Secondary (F vs. A): } \\
\text { 2-h pain-free: } 30 \% \text { vs. } 32 \% \text { (NS) } \\
\text { 2-h pain relief: } 54 \% \text { vs. } 56 \% \text { (NS) } \\
\text { (4-h pain-free \& pain relief: also NS differences) } \\
\text { Recurrence rate within } 48 \text { h: } 30 \% \text { vs. } 44 \%(p<0.05) \\
\text { SPF: } 21 \% \text { vs. } 18 \% \text { (NS) } \\
\text { AEs: NS differences }\end{array}$ & $\begin{array}{l}\text { Frovatriptan } 2.5 \mathrm{mg} \text { has similar efficacy vs. } \\
\text { almotriptan } 12.5 \mathrm{mg} \text {, but has a significantly lower } \\
\text { recurrence rate at } 48 \mathrm{~h} \text {; both are similarly preferred } \\
\text { by patients }\end{array}$ \\
\hline
\end{tabular}

*Note: Some of the trials listed in this table are also included in meta-analyses in Table 3.**2-h/1-h headache response/pain relief/headache relief: reduction in pain from moderate/severe (Grade 2/3) to no/mild pain (Grade 0/1) within 2 hours/1 hour of treatment. $* * * 48$-h SPF $=$ sustained painfree episodes within $48 \mathrm{~h}$ (migraine attack pain-free at $2 \mathrm{~h}$, not recurring and not requiring use of rescue medication or a second study drug dose within $48 \mathrm{~h}$. RCT = randomized, controlled trial; $\mathrm{AEs}=$ adverse events; $\mathrm{P}=$ placebo; $\mathrm{Z}=$ zolmitriptan; $\mathrm{S}=$ sumatriptan; $\mathrm{R}=$ rizatriptan; $\mathrm{N}=$ naratrip$\tan ; \mathrm{A}=$ almotriptan; $\mathrm{E}=$ eletriptan; $\mathrm{F}$ = frovatriptan; $\mathrm{CO}=$ cross-over; $\mathrm{DD}=$ double-dummy; $\mathrm{TD}=$ triple-dummy; $\mathrm{PC}=$ placebo-controlled; $\mathrm{PG}=$ parallel-group; $\mathrm{MC}=$ multicentre; $\mathrm{NS}=$ not statistically significant; $\mathrm{OR}=$ odds ratio; $\mathrm{ITT}=$ intention-to-treat; $\mathrm{NS}=$ not significant; $\mathrm{SPF}=$ sustained pain-free.

$\mathrm{p}<0.001$ ), and no phonophobia (44\% vs. 27\%; p<0.001). Pain intensity differences between treatments were significantly lower in the diclofenac potassium group, starting at 30 minutes post-treatment $(\mathrm{p}=0.013)$, with significant differences at all time points, thereafter $(\mathrm{p}<0.001)$. The most common treatment related adverse event was nausea $(4.6 \%$ for diclofenac potassium vs. $4.3 \%$ for placebo).

\section{Recommendations (diclofenac potassium)}

1. Strong recommendation, high quality evidence: Diclofenac potassium (50 mg tablet or powder for oral solution) is recommended for the acute treatment of migraine attacks of all severities.

2. Strong recommendation, moderate quality evidence: Diclofenac potassium powder for oral solution $(50 \mathrm{mg})$ is recommended for the acute treatment of migraine attacks of all severities for patients desiring a faster onset of therapeutic effect as compared to the diclofenac oral tablet formulation.

\section{e) Acetaminophen}

\section{Evidence Summary}

In a multicentre, randomized, placebo-controlled trial of acetaminophen in adults with migraine, 1,000 $\mathrm{mg}$ doses produced pain relief in $57.8 \%$ of moderate attacks within $2 \mathrm{~h}$ (vs.
$38.7 \%$ for placebo; $\mathrm{p}=0.002)$; $22.4 \%$ of patients were pain-free at $2 \mathrm{~h}$ (vs. $11.3 \%$ for placebo; $\mathrm{p}=0.01$ ). This trial excluded patients with disabling headaches (requiring bed rest or precluding daily activities more than $50 \%$ of the time), or those with vomiting in more than $20 \%$ of attacks. ${ }^{62}$ In another, multicenter, randomized, placebo-controlled trial ( $n=346$ adults with migraine), significantly more patients treated with acetaminophen $(1,000 \mathrm{mg})$ had pain relieved after $2 \mathrm{~h}(52.0 \%)$ compared to those treated with placebo $(32.0 \% ; \mathrm{p}=0.001)$. However, acetaminophen was not significantly better than placebo for pain-free at $2 \mathrm{~h}$. Patients were excluded if they had a history of severely incapacitating migraines with more than $50 \%$ of episodes requiring bed rest (or prohibiting performance of daily activities), or more than $20 \%$ of episodes included vomiting. ${ }^{63}$

A Cochrane systematic review (2010) of acetaminophen for acute migraine headaches in adults $(n=2769 ; 4062$ attacks; see Table 7), which included ten trials (including the two trials discussed above, which contributed almost $99 \%$ of the data for primary outcomes), concluded that acetaminophen 1,000 mg alone may be a useful first-line treatment for individuals with migraine headache that do not cause severe disability. Acetaminophen was superior to placebo, with NNTs of 12.0, 5.2 and 5.0 for 2-h pain-free and 1- and 2-h headache relief, respectively. ${ }^{64}$ When combined with metoclopramide, acetaminophen provided similar efficacy to oral sumatriptan 
Table 5: Triptans - Randomized, double-blind comparative studies versus NSAIDs/analgesic combinations $* 77,79,81,104-108$

\begin{tabular}{|c|c|c|c|}
\hline $\begin{array}{c}\text { Drugs, doses, \# pts included in } \\
\text { analysis (n) }\end{array}$ & $\begin{array}{l}\text { Study design, \# pts included } \\
\text { in analysis (n), primary } \\
\text { endpoints }\end{array}$ & Results & Conclusions/comments \\
\hline $\begin{array}{l}\text { Sumatriptan (S) } 100 \mathrm{mg} \text { vs. lysine } \\
\text { acetylsalicylate } 1620 \mathrm{mg}+ \\
\text { metoclopramide (LAS + M) } 10 \\
\mathrm{mg}^{79}\end{array}$ & $\begin{array}{l}\text { PC, PG, MC, } 2 \text { attack trial; } \\
\mathrm{n}=421 \\
\text { 2-h headache response }{ }^{* *}\end{array}$ & $\begin{array}{l}\text { 2-h headache response (1st } \\
\text { attack): S: 57\%; LAS + M: } \\
53 \%(N S) ; 2-h \text { pain-free } \\
\text { (secondary) } 1^{\text {st }} \text { attack: } \\
\text { S: } 30 \% ; \text { LAS + M: } 22 \% \\
\text { (NS) }\end{array}$ & $\begin{array}{l}\text { Both S \& LAS + M superior to } \\
\text { P; similar efficacy for S and } \\
\text { LAS + M; LAS + M } \\
\text { significantly more effective for } \\
\text { nausea relief than S \& better } \\
\text { tolerated. (Note: lysine } \\
\text { acetylsalicylate is not available } \\
\text { in Canada) }\end{array}$ \\
\hline $\begin{array}{l}\text { Sumatriptan (S) } 100 \mathrm{mg} \text { vs. } \\
\text { tolfenamic acid (TA) } 200 \mathrm{mg}^{104}\end{array}$ & $\begin{array}{l}\text { PC, PG, } 2 \text { attack trial; } \mathrm{n}=141 \\
\text { 2-h headache response } * * ; \\
\text { Difference in headache } \\
\text { severity at } 2 \mathrm{~h} \text { after } 1^{\text {st }} \text { dose }\end{array}$ & $\begin{array}{l}\text { 2-h headache response, } \\
\text { attack 1: S: 79\%; TA: 77\% } \\
\text { (NS); attack 2: S: 64\%; TA } \\
70 \% \text { (NS); Difference in } \\
\text { headache severity at 2h: NS } \\
\text { 2-h pain-free (secondary), } \\
\text { attack 1: S:50\%; TA: } 37 \% \\
\text { (NS); attack 2: S: 26\%; TA } \\
\text { 16\% (NS) }\end{array}$ & $\begin{array}{l}\text { Both S \& TA superior to P; } \\
\text { similar efficacy for TA and S; } \\
\text { similar frequency of AEs } \\
\text { Note: tolfenamic acid is not } \\
\text { available in Canada }\end{array}$ \\
\hline $\begin{array}{l}\text { Sumatriptan (S) } 100 \mathrm{mg} \text { vs. } \\
\text { diclofenac-potassium (DP) } \\
50 / 100 \mathrm{mg}^{105}\end{array}$ & $\begin{array}{l}\mathrm{DD}, \mathrm{CO}, \mathrm{MC}, \text { with-in patient } \\
\text { trial, } 4 \text { attack trial, } 4 \text { treatment } \\
\text { sequences; } \mathrm{n}=144 . \\
\text { Pain intensity via visual } \\
\text { analogue scale (VAS) at } 2 \mathrm{~h} \\
(0=\text { no pain; } 100= \\
\text { excruciating pain \& bed rest })\end{array}$ & $\begin{array}{l}\text { 2-h VAS: NS difference } \\
\text { between S \& DP (both } \\
\text { doses similarly effective); } \\
\text { DP provided significant } \\
\text { pain relief from } 60 \text { min after } \\
\text { dose (S: from } 90 \text { min after } \\
\text { dose); DP superior to S in } \\
\text { reducing nausea }\end{array}$ & $\begin{array}{l}\text { DP is effective, fast-acting and } \\
\text { well tolerated and some } \\
\text { advantages over S; no } \\
\text { advantage of DP } 100 \mathrm{mg} \text { vs. } \\
\text { DP } 50 \mathrm{mg} \text {; unable to evaluate } \\
\text { headache response or pain-free } \\
\text { response from VAS }\end{array}$ \\
\hline $\begin{array}{l}\text { Sumatriptan (S) } 100 \mathrm{mg} \text { vs. ASA } \\
900 \mathrm{mg}+\text { metoclopramide }(\mathrm{A}+ \\
\text { M) } 10 \mathrm{mg}(\mathrm{n}=358)^{106}\end{array}$ & $\begin{array}{l}\text { PG, MC, } 3 \text { attack trial; } \mathrm{n}=358 \\
\text { 2-h headache response** }\end{array}$ & $\begin{array}{l}\text { 2-h headache response (1st } \\
\text { attack): S: } 56 \% \text {; A M: } \\
\text { 45\% (NS); S superior to A + } \\
\text { M for secondary endpoints: } \\
\text { 2-h headache response } \\
\text { (attacks } 2 \& \text { 3), 2-h pain- } \\
\text { free (attacks } 1 \& 3 \text { ) \& } \\
\text { global ratings }\end{array}$ & $\begin{array}{l}66 \% \text { of S patients vs. } 45 \% \text { of } \mathrm{A} \\
+\mathrm{M} \text { patients rated therapy as } \\
\text { reasonable, good or excellent } \\
(\mathrm{p}<0.001)\end{array}$ \\
\hline $\begin{array}{l}\text { Sumatriptan (S) } 50 \mathrm{mg} \\
\text { (encapsulated) vs. effervescent } \\
\text { ASA } 1000 \mathrm{mg} \text { vs. ibuprofen (I) } \\
400 \mathrm{mg}^{107}\end{array}$ & $\begin{array}{l}\mathrm{PC}, \mathrm{DD}, \mathrm{MC}, 3 \text {-fold } \mathrm{CO} ; \\
\mathrm{n}=192 \\
\text { 2-h headache response }\end{array}$ & $\begin{array}{l}\text { 2-h headache response: } \\
\text { ASA: } 52.5 \% \text {; I: } 60.2 \% ; \mathrm{S} \text { : } \\
55.8 \%(\mathrm{NS})\end{array}$ & $\begin{array}{l}\text { Effervescent ASA } 1,000 \mathrm{mg} \text { is } \\
\text { as effective as } \mathrm{S}-50 \mathrm{mg} \text { and I- } \\
400 \mathrm{mg} \text { but } \mathrm{S} \text { more effective } \\
\text { for pain-free at } 2 \mathrm{~h}\end{array}$ \\
\hline $\begin{array}{l}\text { Sumatriptan (S) } 50 \mathrm{mg} \text { vs. AAC } \\
\text { (acetaminophen } 500 \mathrm{mg} \text {, ASA } \\
500 \mathrm{mg} \text {, caffeine } 130 \mathrm{mg} \text { ); all } \\
\text { encapsulated }^{108}\end{array}$ & $\begin{array}{l}\text { PC, MC; } 2: 2: 1 \text { randomization; } \\
\text { drugs taken at first sign of } \\
\text { migraine attack; } n=171 \\
\text { Sum of pain intensity } \\
\text { differences from baseline at } 4 \\
\text { h post-dose (SPID4) }\end{array}$ & $\begin{array}{l}\text { SPID4: significantly greater } \\
\text { in AAC group vs. S group }\end{array}$ & $\begin{array}{l}\text { AAC significantly superior to } \\
\text { S taken at first sign of attack; } \\
\text { encapsulation may affect } \\
\text { kinetics; excluded patients with } \\
\text { vomiting }>20 \% \text { of attacks or } \\
\text { bed rest }>50 \% \text { of attacks } \\
\text { (Note: AAC combination is not } \\
\text { available in Canada) }\end{array}$ \\
\hline $\begin{array}{l}\text { Sumatriptan (S) } 50 \mathrm{mg} \\
\text { (encapsulated) vs. domperidone } \\
\text { (DO) } 10 \mathrm{mg}+\text { acetaminophen } \\
\text { (AC) } 500 \mathrm{mg} \text { (fixed combination) } \\
(\mathrm{n}=161)^{81}\end{array}$ & $\begin{array}{l}\mathrm{DD}, \mathrm{PC}, \mathrm{CO}, \mathrm{MC}, 2 \text { attack } \\
\text { trial; } \mathrm{n}=171 \\
\text { 2-h headache response }{ }^{* *}\end{array}$ & $\begin{array}{l}\text { 2-h headache response: } \\
\text { S: } 33.3 \% \text {; DO/AC: } 36.4 \% \\
\text { (NS); NS difference for } \\
\text { nausea/vomiting reduction } \\
\text { by both }\end{array}$ & $\begin{array}{l}\text { Similar efficacy for both; low } \\
\text { 2-h response rates for both } \\
\text { (reason unknown); (Note: } \\
\text { DO/AC fixed combination is } \\
\text { not available in Canada) }\end{array}$ \\
\hline $\begin{array}{l}\text { Zolmitriptan (Z) } 2.5 \mathrm{mg} \text { vs. ASA } \\
900 \mathrm{mg}+\text { metoclopramide }(\mathrm{A}+ \\
\text { M) } 10 \mathrm{mg}^{77}\end{array}$ & $\begin{array}{l}\text { MC, } P G, 3 \text { attacks; } n=666 \\
\text { 2-h headache response** }\end{array}$ & $\begin{array}{l}\text { 2-h headache response ( } 3 \text { of } \\
3 \text { attacks): } \\
\text { Z: } 33.4 \% ; \mathrm{A}+\mathrm{M}: 32.9 \% \\
\text { (NS); } \\
\text { Pain-free at } 2 \mathrm{~h} \text { (secondary): } \\
\mathrm{Z}: 10.7 \% ; \mathrm{A}+\mathrm{M}: 5.3 \% \\
\text { (significant) }\end{array}$ & $\begin{array}{l}\text { Possible selection bias (mostly } \\
\text { good responders to A + M; } \\
\text { mostly triptan-naïve); both } \\
\text { well-tolerated; higher pt } \\
\text { satisfaction with } Z \text { vs. A + M } \\
(83 \% \text { vs. } 75 \%, p=0.03)\end{array}$ \\
\hline
\end{tabular}

*Note: some of the trials listed in this table are also included in meta-analyses in Tables 3 and 7. ** 2-h headache response: reduction in pain from severe/moderate to mild/no pain within 2 hours of treatment. $\mathrm{P}=$ placebo; $\mathrm{PC}=$ placebo-controlled; $\mathrm{DD}=$ doubledummy; $\mathrm{PG}=$ parallel group $\mathrm{MC}=$ multicentre, $\mathrm{CO}=$ cross-over; $\mathrm{NS}=$ not statistically significant AEs $=$ adverse events 
Table 6: Triptans - Early intervention: randomized, double-blind, prospective trials ${ }^{27-33}$

\begin{tabular}{|c|c|c|c|}
\hline $\begin{array}{l}\text { Drug and } \\
\text { dose }\end{array}$ & $\begin{array}{l}\text { Study design, \# patients included in } \\
\text { analysis (n), primary endpoints }\end{array}$ & Results & Comments/conclusions \\
\hline $\begin{array}{l}\text { Zolmitriptan } \\
2.5 \mathrm{mg} \mathrm{oral}^{27}\end{array}$ & $\begin{array}{l}\text { RA, DB, PC, PG; } \mathrm{n}=280 \\
\text { Pain-free at } 2 \mathrm{~h} \text { : attacks treated during } \\
\text { mild phase within } 4 \mathrm{~h} \text { of onset (time to } \\
\text { treatment was recorded) vs. placebo }\end{array}$ & $\begin{array}{l}\text { Pain-free at } 2 \mathrm{~h}(\text { all pts): } \\
\mathrm{Z}: 43.4 \% ; \mathrm{P}: 18.4 \%(p<0.0001) \\
\text { Pain-free at } 2 \mathrm{~h}(\text { treated within } 15 \\
\text { min of onset): } \\
\text { Z: } 57 \% ; \mathrm{P}: 20 \%(\mathrm{p}<0.001)\end{array}$ & $\begin{array}{l}\text { Most pts treated early ( }>50 \% \text { within } 30 \text { min } \\
\text { of onset); high pain-free rates with treatment } \\
\text { while pain is mild \& } \downarrow \text { progression to more } \\
\text { severe migraine; lower incidence of adverse } \\
\text { effects with early treatment }\end{array}$ \\
\hline $\begin{array}{l}\text { Frovatriptan } \\
2.5 \text { mg oral } \\
(2 \text { attacks })^{28}\end{array}$ & $\begin{array}{l}\text { RA, DB, PC, two-way crossover: } \\
\text { Dose } 1 \text { taken at onset of mild headache } \\
\text { pain; Dose } 2 \text { could be taken from } 2 \mathrm{~h} \\
\text { after Dose } 1 \text {, only if headache } \\
\text { progresses to moderate or severe (one } \\
\text { dose active, other placebo; dosing order } \\
\text { reversed for attack } 2 \text { ); } \mathrm{n}=241 \\
\text { Pain-free at } 2 \mathrm{~h} \text { (Dose } 1 \text { ); use of Dose } 2 \\
\text { and/or rescue meds, pain severity, } \\
\text { functional impairment, headache } \\
\text { recurrence }\end{array}$ & $\begin{array}{l}\text { Pain-free at } 2 \mathrm{~h}: \\
\mathrm{F}: 28 \% ; \mathrm{P}: 20 \%(\mathrm{p}=0.04) \text {; benefit } \\
\text { sustained up to } 4 \mathrm{~h} \text { post-dose } \\
(p=0.003) \text { Sustained pain-free: } \\
40 \% \text { with early use of } \mathrm{F} \text { vs. } 31 \% \\
\text { with later use }(p<0.05) \\
\text { Early use of } \mathrm{F} \text { : sign. } \downarrow \text { re-medication } \\
(p<0.001) \text {, prevented headache } \\
\text { progression }(p<0.001), \downarrow \text { pain burden } \\
\& \text { functional disability }(p \leq 0.001)\end{array}$ & $\begin{array}{l}\text { Early use of F resulted in higher, earlier and } \\
\text { sustained pain-free response, prevented } \\
\text { progression to moderate/severe headache and } \\
\downarrow \text { pain burden \& functional disability; long } \\
\text { half-life of F - suitability for early } \\
\text { intervention }\end{array}$ \\
\hline $\begin{array}{l}\text { Sumatriptan } \\
50 / 100 \mathrm{mg} \\
\text { oral }^{33}\end{array}$ & $\begin{array}{l}\text { RA, DB, DD, PC, PG ( } 2 \text { identical } \\
\text { trials); } 1: 1: 1 \text { ratio S- } 50 \mathrm{mg}, \mathrm{S}-100 \mathrm{mg} \text {, } \\
\mathrm{P} \text {; pts treated attacks at first sign of } \\
\text { pain, while mild pain (not more than } 2 \\
\text { h after onset); } \mathrm{n}=354 \text { (study } 1 \text { ); } \mathrm{n}=337 \\
\text { (study 2) Pain-free at } 2 \mathrm{~h} \text { (S-50 mg vs. } \\
\text { P) (primary endpoint) }\end{array}$ & $\begin{array}{l}\text { Pain-free at } 2 \mathrm{~h} \text { (pooled results): } \\
\text { S-50 mg: } 50 \% \text {; P: } 29 \%(p<0.001) \\
\text { S-100 mg: } 57 \% \text {; P: } 29 \%(p<0.001)\end{array}$ & $\begin{array}{l}\text { Treatment of migraine at first sign of pain } \\
\text { with } S-50 / 100 \mathrm{mg} \text { provides superior pain-free } \\
\text { relief at } 2 \& 4 \mathrm{~h} \text { vs. } \mathrm{P} \text {; } \mathrm{S} \text { provided freedom } \\
\text { from migraine-associated symptoms in most } \\
\text { patients at } 2 \mathrm{~h}\end{array}$ \\
\hline $\begin{array}{l}\text { Eletriptan } \\
20 / 40 \mathrm{mg} \\
\text { oral }^{29}\end{array}$ & $\begin{array}{l}\text { RA, DB, PC, PG ( } 33 \text { centres); } \mathrm{n}=565 \\
1: 1: 1 \text { ratio E- } 20 \mathrm{mg}, \mathrm{E}-40 \mathrm{mg}, \mathrm{P} ; \\
\text { patients treated attacks as soon as sure } \\
\text { they had typical migraine headache } \\
\text { (after aura phase ended) \& encouraged } \\
\text { (not required) to take study med when } \\
\text { pain was mild } \\
\text { Pain-free at } 2 \mathrm{~h}\end{array}$ & $\begin{array}{l}\text { Pain-free at } 2 \mathrm{~h} \text { (all patients; treated } \\
\text { at any baseline severity): } \\
\text { E-20 mg: } 35 \% \text {; : } 22 \%(p<0.01) \\
\text { E-40 mg: } 47 \% ; \text { P: } 22 \%(p<0.0001) \\
\text { Pain-free at } 2 \text { h (treated when pain } \\
\text { was mild): E-40 mg: } 68 \% ; \text { P: } 25 \% \\
(p<0.0001) \text { (for E-20 mg: NS) }\end{array}$ & $\begin{array}{l}\text { Early treatment with E-40 mg when pain was } \\
\text { mild resulted in higher pain-free and sustainer } \\
\text { pain-free rates; sustained pain-free maintainer } \\
\text { over } 24 \text { h post-dose with E vs. P }\end{array}$ \\
\hline $\begin{array}{l}\text { Sumatriptan } \\
\text { oral fast- } \\
\text { disintegrating } \\
50 / 100 \mathrm{mg}^{30}\end{array}$ & $\begin{array}{l}\text { RA, DB, PC, PG ( } 54 \text { centres }) ; \mathrm{n}=432 \\
1: 1: 1 \text { ratio } \mathrm{S}-50 \mathrm{mg}, \mathrm{S}-100 \mathrm{mg}, \mathrm{P} ; \\
\text { patients treated attack within } 1 \mathrm{~h} \text { of } \\
\text { onset of mild pain \& only while pain } \\
\text { was mild } \\
\text { Pain-free at } 2 \mathrm{~h}\end{array}$ & $\begin{array}{l}\text { Pain-free at } 2 \text { h: } \\
\text { S-50 mg: } 51 \% ; \text { P: } 20 \%(p<0.001) \mathrm{S}- \\
100 \mathrm{mg}: 66 \% ; \mathrm{P}: 20 \%(p<0.001) \\
\text { Normal function restored in sign. } \\
\text { greater } \% \text { pts }(\mathrm{p}<0.05) \text { treated with } \mathrm{S} \\
\text { vs. P from } 45 \mathrm{~min} \text { post-dose for } \mathrm{S}- \\
100 \mathrm{mg} \& 1 \mathrm{~h} \text { post-dose for S-50 mg } \\
\text { Median lost time equivalents (during } \\
24 \text { h post-dose; paid work \& } \\
\text { activities outside paid work) sign. } \\
\text { lower in each S group vs. P }\end{array}$ & $\begin{array}{l}\text { S fast disintegrating oral formulation confers } \\
\text { rapid, sustained restoration of functional } \\
\text { ability }\end{array}$ \\
\hline $\begin{array}{l}\text { Sumatriptan } \\
50 / 100 \mathrm{mg} \\
\text { oral }^{31}\end{array}$ & $\begin{array}{l}\text { RA, DB, PC, PG ( } 25 \text { centres }) ; n=361 \\
1: 1: 1 \text { ratio } S-50 \mathrm{mg}, \mathrm{S}-100 \mathrm{mg}, \mathrm{P} ; \\
\text { patients treated attack within } 2 \mathrm{~h} \text { of first } \\
\text { sign of migraine pain \& only while pain } \\
\text { was mild. Pain-free at } 2 \mathrm{~h}\end{array}$ & $\begin{array}{l}\text { Pain-free at } 2 \mathrm{~h}: \\
\text { S-50 mg: } 40 \% ; \mathrm{S}-100 \mathrm{mg}: 50 \% ; \mathrm{P}: \\
16 \%(p<0.001, \text { active groups vs. P) }\end{array}$ & $\begin{array}{l}\text { Both doses of S significantly superior to } \mathrm{P} \text { for } \\
\text { 2-h pain-free; higher pain-free rates when } \mathrm{S} \\
\text { taken while headache was mild vs. older trials } \\
\text { (taken when moderate or severe pain) }\end{array}$ \\
\hline $\begin{array}{l}\text { Rizatriptan } 10 \\
\text { mg oral }^{32}\end{array}$ & $\begin{array}{l}\text { Two studies (TAME1, TAME2): RA, } \\
\text { DB, PC, PG (46 centres); } n=1030 ; 2: 1 \\
\text { ratio R } 10 \mathrm{mg} \text { vs. P; patients treated } \\
\text { within } 1 \mathrm{~h} \text { of migraine onset, while pain } \\
\text { was mild } \\
\text { Pain-free at } 2 \mathrm{~h} \& \text { sustained pain-free at } \\
24 \mathrm{~h}\end{array}$ & $\begin{array}{l}\text { TAME1: Pain-free at } 2 \mathrm{~h}: \mathrm{R}: 57.3 \% \\
\text { P: } 31.1 \%(p<0.001) \text { Sustained pain- } \\
\text { free at } 24 \text { h: R: } 42.6 \% ; \text { P: } 23.2 \% \\
(p<0.001) \\
\text { TAME2: Pain-free at } 2 \mathrm{~h}: \mathrm{R}: 58.9 \% \\
\text { P: } 31.1 \%(p<0.001) \\
\text { Sustained pain-free at } 24 \mathrm{~h}: \mathrm{R}: \\
48.0 \% ; \mathrm{P}: 24.6 \%(p<0.001)\end{array}$ & $\begin{array}{l}\mathrm{R} 10 \mathrm{mg} \text { significantly superior to } \mathrm{P} \text { when } \\
\text { treating migraine early, while pain is mild }\end{array}$ \\
\hline
\end{tabular}

$\mathrm{P}=$ placebo; $\mathrm{Z}=$ zolmitriptan $; \mathrm{F}=$ frovatriptan $\mathrm{S}=$ sumatriptan $\mathrm{E}=$ eletriptan RA = randomized $\mathrm{CO}=$ controlled; $\mathrm{DB}=$ doubleblind; $\mathrm{PC}=$ placebo-controlled; $\mathrm{PG}=$ parallel group; $\mathrm{DD}=$ double dummy; $\mathrm{NS}=$ not statistically significant 
$100 \mathrm{mg}$ for $2 \mathrm{~h}$ headache relief (no pain-free data), and relief of photophobia and phonophobia, but with fewer adverse effects than sumatriptan. 64

\section{Recommendation (acetaminophen)}

1. Strong recommendation, high quality evidence: Acetaminophen (1,000 mg), alone or in combination with oral metoclopramide (10 $\mathrm{mg}$ ), is recommended for the acute treatment of mild or moderate migraine attacks.

Opioid- and Tramadol-containing Products

\section{a) Oral Opioid-containing Products}

\section{Overview}

Opioids are associated with significant adverse effects including sedation, dizziness, constipation, tolerance, dependence, and abuse potential. There is also a significant risk of medication overuse headache with frequent use of opioidcontaining combination products..$^{1,65}$

\section{Evidence Summary}

Oral opioids (e.g., codeine, morphine, hydromorphone, meperidine) and opioid-containing combination products (e.g., ASA/acetaminophen plus codeine) may relieve acute migraine pain in some patients; however, they may aggravate migraineassociated nausea and vomiting. There is a lack of randomized, controlled trials assessing the efficacy of oral opioids and combination products for the symptomatic treatment of migraine. One randomized, double-blind, placebo-controlled trial which compared an acetaminophen-codeine combination to ASA, found no significant difference, although both were superior to placebo in the treatment of acute migraine attacks. ${ }^{66}$

\section{b) Intranasal Butorphanol}

\section{Overview}

Butorphanol tartrate is a potent, synthetic mixed agonistantagonist opioid analgesic for use in the relief of moderate to severe pain. Although butorphanol is not a pure agonist and, theoretically, may have less addiction potential than pure agonists (e.g., hydromorphone, morphine, meperidine), it is associated with similar adverse effects, and the potential for medication overuse headache and abuse/dependence. There have been widespread reports of abuse and dependence, primarily in migraine patients. Butorphanol has effects at the kappa opioid receptor, which can produce unpleasant emotional sensations and dysphoria. ${ }^{67}$

\section{Evidence Summary}

At the time of marketing, clinical trial experience with butorphanol nasal spray in migraineurs was limited. Subjects with frequent or refractory headache, or those with a prior history of substance abuse, were excluded from butorphanol trials. ${ }^{67}$ Butorphanol nasal spray has been shown to be effective in rapidly relieving pain associated with acute migraine (moderate to severe) in two randomized, double-blind, placebocontrolled trials. ${ }^{68,69}$ In a randomized, controlled, double-blind, parallel-group trial $(\mathrm{n}=275$ in efficacy analysis), butorphanol
$1 \mathrm{mg}$ nasal spray was compared to a combination of butalbital $50 \mathrm{mg}$, caffeine $40 \mathrm{mg}$, ASA $325 \mathrm{mg}$, and codeine phosphate $30 \mathrm{mg}$ in patients with moderate to severe migraine. ${ }^{69}$ Butorphanol nasal spray was more effective than the butalbitalcontaining combination in treating migraine pain (primary efficacy measure was pain intensity difference during first two hours); butorphanol had a rapid time to onset of 15 minutes; however, it was associated with more side effects than the butalbital-containing product.

\section{c) Oral Tramadol plus Acetaminophen}

\section{Overview}

Tramadol is an analgesic that binds weakly to $\mu$-opioid receptors, and also inhibits serotonin and norepinephrine reuptake. As with opioids, tramadol use is associated with adverse effects such as central nervous system (CNS) depression and respiratory depression, dependence, withdrawal reactions, and the potential for abuse (less potential for abuse than opioids)..$^{70-72}$

\section{Evidence Summary}

There is one published randomized, multicentre, placebocontrolled trial of oral tramadol and acetaminophen combination ( 2 tablets: total dose $75 \mathrm{mg} / 650 \mathrm{mg}$; $\mathrm{n}=305$ ) in acute migraine. ${ }^{73}$ At $2 \mathrm{~h}$ after dosing, the treatment response (i.e., headache relief; primary endpoint) for tramadol/acetaminophen was $55.8 \%$ vs. $33.8 \%$ for placebo $(\mathrm{p}<0.001)$; subjects in the tramadol/ acetaminophen group were more likely than those in the placebo group to be pain-free at $2 \mathrm{~h}(22.1 \%$ vs. 9.3\%; p $\leq 0.007)$. Photophobia and phonophobia were significantly less common with tramadol/acetaminophen than placebo at $2 \mathrm{~h}$, but not migraine-related nausea. Treatment-related adverse events included nausea, dizziness, vomiting, and somnolence.

\section{Recommendations (opioids and tramadol)}

1. Strong recommendation, low quality evidence: Oral opioids, including codeine, are not recommended for routine use in migraine, due to lack of evidence for superiority to standard drugs (NSAIDs and triptans), and the risk of dependencelabuse, potential for development of medication overuse headache, and the possibility of a withdrawal syndrome following discontinuation.

2. Weak recommendation, low quality evidence: Codeinecontaining combination analgesics may be considered for patients with moderate or severe migraine attacks when triptan and/or NSAIDs are ineffective or contraindicated, and for occasional use as rescue medication when the patient's regular medication has failed. Frequency of use should be closely monitored, preferably with use of headache diaries.

3. Strong recommendation, low quality evidence: Tramadol alone or in combination with acetaminophen is not recommended for routine use in migraine, due to lack of evidence for superiority to standard drugs (NSAIDs and triptans), and the risk of dependencelabuse, potential for development of medication overuse headache, and the possibility of a withdrawal syndrome following discontinuation. 
4. Weak recommendation, moderate quality evidence: Tramadol in combination with acetaminophen may be considered for patients with moderate or severe migraine attacks when triptans and/or NSAIDs are ineffective or contraindicated, and for occasional use as rescue medication when the patient's regular medication has failed. Frequency of use should be closely monitored, preferably with use of headache diaries.

5. Strong recommendation, low quality evidence: Butorphanol nasal spray, although effective for acute migraine, should be avoided (except in exceptional circumstances) for the acute treatment of migraine, due to lack of evidence for superiority to standard drugs (NSAIDs and / or triptans), risk of dependencelabuse, potential for development of medication overuse headache, and the possibility of a withdrawal syndrome following discontinuation. When used, frequency of use should be closely monitored, preferably with use of headache diaries.

\section{Barbiturate (Butalbital)-containing Products}

\section{Overview}

Butalbital-containing products are associated with significant adverse effects (e.g., sedation, intoxication similar to that produced by alcohol), risk of dependence, abuse potential, risk of medication-overuse headache with frequent use, and a severe withdrawal syndrome (including seizures) on discontinuation of high doses. ${ }^{1,65,74,75}$

\section{Evidence Summary}

A qualitative systematic search (1966-2001) concluded that although butalbital-containing products are commonly prescribed for migraine, no evidence in the literature has demonstrated their benefit over other agents or placebo. ${ }^{74}$ In a randomized, controlled trial $(n=275$ in efficacy analysis) comparing butorphanol nasal spray to a combination of butalbital $50 \mathrm{mg}$, caffeine $40 \mathrm{mg}$, ASA $325 \mathrm{mg}$, and codeine phosphate $30 \mathrm{mg}$, the butalbital-containing combination was inferior to butorphanol in treating migraine pain. ${ }^{69}$

In a recent, randomized, double-blind, placebo-controlled trial $(n=442)$, a butalbital-acetaminophen-caffeine containing combination analgesic was compared to a sumatriptan-naproxen sodium combination. ${ }^{76}$ For inclusion, all patients were required to have used butalbital compounds in the past (butalbital responders), and in fact $88 \%$ of subjects who entered the study reported current use of butalbital compounds. The study population may have been biased, therefore, in favour of subjects who respond to butalbital-containing analgesics. Despite this, although both the butalbital-containing analgesic and the sumatriptan-naproxen sodium compound were superior to placebo, the sumatriptan-naproxen sodium compound was superior to the butalbital compound on most secondary endpoints, although not for the primary endpoint of sustained pain-free, where there was no significant difference. This study demonstrated that butalbital-containing analgesics may have efficacy in the treatment of acute migraine attacks, but are not superior to an NSAID-triptan combination. ${ }^{76}$ Therefore, given the potential problems with butalbital-containing compounds, it would seem difficult to justify their use in acute migraine except for exceptional circumstances.

\section{Recommendation (barbiturates)}

1. Strong recommendation, low quality evidence: Barbiturate (i.e., butalbital)-containing combination analgesics should be avoided (except in exceptional circumstances) for the acute treatment of migraine, due to lack of evidence for superiority to standard drugs (NSAIDs and / or triptans), risk of dependencelabuse, potential for development of medication overuse headache, and the possibility of a withdrawal syndrome following discontinuation of high doses.

\section{Adjunctive Drugs}

\section{Overview}

Adjunctive therapies may be used to relieve associated symptoms of migraine (e.g., nausea, vomiting), enhance gastric emptying, or to improve efficacy of acute migraine therapies. Parenteral dopamine antagonists (e.g., metoclopramide, prochlorperazine; administered in the emergency room), used as monotherapy, are effective in relieving migraine-associated nausea, as well as headache (not included in this guideline). In outpatient practice, adjunctive drugs are often used in combination with other effective migraine treatments. ${ }^{1}$ There are randomized controlled trials for oral metoclopramide and domperidone as adjunctive drugs in the outpatient setting. Oral or rectal prochlorperazine may be used for relief of migraineassociated nausea and vomiting but there is a lack of RCTs. Although dimenhydrinate is often used by patients for nausea and vomiting associated with migraine, there are no RCTs to support its use, and metoclopramide would appear to be a better choice for most patients based on evidence for efficacy.

\section{Evidence Summary}

\section{a) Metoclopramide}

Metoclopramide has shown efficacy in combination with other acute therapies. ${ }^{77-79}$ A Cochrane systematic review of ASA with or without metoclopramide (see Acetylsalicylic Acid section and Table 7) concluded that the addition of oral metoclopramide $(10 \mathrm{mg})$ to ASA $1,000 \mathrm{mg}$ improves relief of nausea and vomiting. ${ }^{49}$ Limitations of metoclopramide include adverse effects such as sedation, extrapyramidal effects, and the relatively uncommon risk of tardive dyskinesia.

Metoclopramide may improve the efficacy of triptans. In a small, double-blind, randomized, crossover study of 16 adult migraineurs who had failed to receive adequate relief from triptans (i.e., adequate doses of at least two separate trials of the same triptan, or at least two trials involving different triptans) treated one migraine with each treatment: sumatriptan $50 \mathrm{mg}$ plus metoclopramide $10 \mathrm{mg}$, or sumatriptan $50 \mathrm{mg}$ plus placebo. Patients treated their migraines when they were moderate or severe in intensity. Meaningful relief was attained in $10(63 \%)$ of 16 migraines treated with the combination of sumatriptan plus metoclopramide, compared with $5(31 \%)$ of 16 migraines treated with sumatriptan plus placebo. The combination was well tolerated. Whether initiating therapy when pain was mild or 
Table 7: Meta-analyses/systematic reviews of acetaminophen, ASA and NSAIDs for acute migraine treatment [part 1] $31,32,49,50,55,59,64$

\begin{tabular}{|c|c|c|c|}
\hline $\begin{array}{l}\text { Drug (publication date); } \\
\text { number of trials included; } \\
\text { number of participants } \\
\text { (n); types of participants }\end{array}$ & Objective & Efficacy outcomes and main results & Conclusions and limitations \\
\hline $\begin{array}{l}\text { Types of participants: } \\
\text { adults ( } \geq 18 \text { years); IHS } \\
\text { criteria for migraine } \\
\text { diagnosis; stable } \\
\text { prophylactic therapy } \\
\text { allowed }\end{array}$ & $\begin{array}{l}\text { To determine } \\
\text { efficacy and } \\
\text { tolerability of } \\
\text { acetaminophen, alone } \\
\text { or in combination } \\
\text { with antiemetic vs. } \\
\text { placebo or other } \\
\text { active interventions } \\
\text { in treatment of acute } \\
\text { migraine in adults }\end{array}$ & $\begin{array}{l}\text { Primary efficacy outcomes: pain-free at } 2 \mathrm{~h} \text {, without use of rescue medications; } \\
\text { headache relief* at } 1 \mathrm{~h} \& 2 \mathrm{~h} \text {; sustained pain-free** over } 24 \mathrm{~h} \text {; sustained pain } \\
\text { reduction*** over } 24 \mathrm{~h} \\
\text { Main results: Acetaminophen } 1,000 \mathrm{mg} \text { vs. placebo: } 2 \text {-h pain-free: } 19 \% \text { vs. } 10 \% \\
\text { (NNT=12) } \\
\text { 1-h headache relief: } 39 \% \text { vs. } 20 \% \text { (NNT=5.2) } \\
\text { 2-h headache relief: } 56 \% \text { vs. } 36 \% \text { (NNT=5) } \\
\text { Nausea photophobia \& phonophobia reduced more with acetaminophen vs. } \\
\text { placebo at } 2 \text { h (NNTs of } 7-11 \text { ); more individuals were free of functional disability } \\
\text { at } 2 \mathrm{~h} \text { with acetaminophen (NNT=10) \& fewer needed rescue medication over } 6 \mathrm{~h} \\
\text { (NNT=6) } \\
\text { Acetaminophen } 1,000 \text { mg + metoclopramide } 10 \text { mg vs. sumatriptan } 100 \mathrm{mg} \text { : } \\
\text { 2-h headache relief: } 39 \% \text { vs. } 42 \% \text { (NS; NNT not calculated); no 2-h pain-free } \\
\text { data; NS difference in relief of photophobia \& phonophobia at } 2 \mathrm{~h} \text { ) } \\
\text { AE rates similar for acetaminophen vs. placebo, and between acetaminophen + } \\
\text { metoclopramide \& sumatriptan; more "major" adverse events occurred with } \\
\text { sumatriptan (NNH=32) }\end{array}$ & $\begin{array}{l}\text { Acetaminophen } 1,000 \mathrm{mg} \text { alone is an effective treatment for } \\
\text { acute migraine headaches; the addition of metoclopramide } 10 \\
\text { mg gives short-term efficacy equivalent to oral sumatriptan } \\
100 \mathrm{mg} \text {. } \\
\text { AEs with acetaminophen did not differ from placebo; "major" } \\
\text { AEs were slightly more common with sumatriptan than with } \\
\text { acetaminophen + metoclopramide. } \\
\text { Note: potential for hepatotoxicity with acetaminophen } \\
\text { Limitations: data not reported consistently for some } \\
\text { outcomes; single-dose comparisons; no data on prevention of } \\
\text { recurrence with acetaminophen; } 2 \text { studies } 2 \text { (2,63 contributed } \\
\text { almost } 90 \% \text { of data for primary outcomes; some individuals } \\
\text { with very severe or difficult-to-treat migraine attacks may hav } \\
\text { been excluded, and limits on frequency of attacks would } \\
\text { exclude those with very frequent attacks; patients with } \\
\text { significant co-morbidities were excluded from most studies; } \\
\text { limited data with respect to active comparators other than } \\
\text { sumatriptan }\end{array}$ \\
\hline $\begin{array}{l}\text { Ibuprofen }(2007)^{51} \\
5 \text { RCTs } \\
\mathrm{n}=1353 \text { (pain relief) } \\
\mathrm{n}=2161 \text { (pain-free) } \\
\\
\text { Types of participants: } \\
\text { age } \geq 16 \text { years; moderate or } \\
\text { severe migraine attacks }\end{array}$ & $\begin{array}{l}\text { To evaluate efficacy } \\
\text { of low-dose } \\
\text { ibuprofen ( } 200 \text { or } \\
400 \mathrm{mg} \text { ) for } \\
\text { treatment of acute } \\
\text { migraine attack }\end{array}$ & $\begin{array}{l}200 \mathrm{mg} \text { dose: } \mathrm{NNT}=8 \text { ( } 95 \% \mathrm{CI} 5-20) \text { for pain relief at } 2 \mathrm{~h} \& \mathrm{NNT}=13(95 \% \mathrm{CI} \\
\text { 8-50) for pain-free } \\
400 \mathrm{mg} \text { dose: } \mathrm{NNT}=4 \text { ( } 95 \% \mathrm{CI} 3-7) \text { for pain relief at } 2 \mathrm{~h} \& \mathrm{NNT}=9(95 \% \mathrm{CI} 5- \\
20) \text { for pain-free } \\
\text { 24-h sustained pain-free for ibuprofen was no better than placebo } \\
400 \mathrm{mg} \text { dose: relief in photophobia }=30 \%(95 \% \mathrm{CI} 8-57 ; p<0.01) \& \text { phonophobia } \\
=49 \%(95 \% \mathrm{CI} 23-81 ; p<0.0001)\end{array}$ & $\begin{array}{l}\text { Ibuprofen }(200 \& 400 \mathrm{mg} \text { ) is effective in reducing headache } \\
\text { intensity \& rendering adult patients pain-free at } 2 \mathrm{~h} \text {; } \\
\text { photophobia \& phonophobia improved with } 400 \mathrm{mg} \text { dose only } \\
\text { AEs were similar for ibuprofen \& placebo. } \\
\text { Limitations: individual study designs/small sample size; } \\
\text { inconsistencies in descriptions of outcomes; too few studies to } \\
\text { allow sub-group analysis }\end{array}$ \\
\hline $\begin{array}{l}\text { Types of participants: } \\
\text { adults ( } \geq 18 \text { years); IHS } \\
\text { criteria for migraine } \\
\text { diagnosis; stable } \\
\text { prophylactic therapy } \\
\text { allowed }\end{array}$ & $\begin{array}{l}\text { To determine safety } \\
\text { and efficacy of } \\
\text { ibuprofen, alone or in } \\
\text { combination with } \\
\text { antiemetic, compared } \\
\text { to placebo and other } \\
\text { active interventions } \\
\text { in treatment of acute } \\
\text { migraine headaches } \\
\text { in adults }\end{array}$ & $\begin{array}{l}\text { Primary efficacy outcomes: pain-free at } 2 \mathrm{~h} \text { without use of rescue medications; } \\
\text { headache relief* at } 1 \mathrm{~h} \& 2 \mathrm{~h} \text {; sustained pain-free** over } 24 \mathrm{~h} \text {; sustained pain } \\
\text { reduction*** over } 24 \mathrm{~h} \\
\text { Main results: Ibuprofen } 400 \mathrm{mg} \text { vs. placebo: } 2 \text {-h pain-free ( } 26 \% \text { vs. } 12 \% \text { ): } \\
\text { NNT=7.2 } \\
\text { 2-h headache relief ( } 57 \% \text { vs. } 25 \% \text { ) NNT }=3.2 \\
\text { 24-h sustained headache relief ( } 45 \% \text { vs. } 19 \% \text { ): NNT=4.0 } \\
\text { Ibuprofen } 200 \mathrm{mg} \text { vs. placebo: } 2 \text {-h pain-free ( } 20 \% \text { vs. } 10 \% \text { ): NNT=9.7 } \\
\text { 2-h headache relief ( } 52 \% \text { vs. } 37 \% \text { ): NNT=6.3 } \\
\text { Ibuprofen } 400 \mathrm{mg} \text { solubilized vs. standard tablets (no head-to-head trials): } 1 \text {-h } \\
\text { headache relief: NNT=3.9 vs. NNT=8.3 ( } p=0.0114) .2 \text {-h headache relief: NS } \\
\text { difference } \\
\text { Significant relief of migraine associated symptoms after } 2 \mathrm{~h} \text { with ibuprofen vs. } \\
\text { placebo (trend to lower NNT with } 400 \text { mg vs. } 200 \text { mg ibuprofen) in } 4 \text { studies } \\
\text { AEs mostly mild and transient, with similar rate to placebo; } 2 \text { serious AEs with } \\
\text { ibuprofen (perforation of duodenal ulcer; death due to sepsis - not related to study } \\
\text { medication) }\end{array}$ & $\begin{array}{l}\text { Ibuprofen is an effective treatment for acute migraine } \\
\text { headaches, providing pain relief in about half of sufferers, but } \\
\text { complete relief from pain and associated symptoms for only a } \\
\text { minority; NNT for ibuprofen } 400 \mathrm{mg} \text { significantly superior to } \\
200 \mathrm{mg} \text { for 2-h pain relief only. } \\
\text { Results are similar to those for ASA } 900 \mathrm{mg} \text { or } 1000 \mathrm{mg} \text {, with } \\
\text { ibuprofen } 400 \mathrm{mg} \text { performing slightly better than ASA, and } \\
\text { ibuprofen } 200 \mathrm{mg} \text { slightly worse [see ASA } \pm \text { antiemetic (2010, } \\
\text { below]. } \\
\text { Solubilized formulations (e.g., liquigel) were superior for 1-h } \\
\text { but not 2-h headache relief vs. standard tablets. } \\
\text { AEs were mostly mild and transient with ibuprofen. } \\
\text { Limitations: small number of events used to calculate some } \\
\text { results, particularly for specific AEs and for presence and relie } \\
\text { of vomiting at } 2 \mathrm{~h} \text { (fewer than } 100 \text { participants had vomiting at } \\
\text { baseline) }\end{array}$ \\
\hline $\begin{array}{l}\text { Naproxen Sodium } \\
(2010)^{55} \\
4 \text { RCTs } \\
\mathrm{n}=2168 \\
\text { Types of participants: } \\
\text { adults; moderate to severe } \\
\text { attacks }\end{array}$ & $\begin{array}{l}\text { To assess efficacy \& } \\
\text { safety of naproxen } \\
\text { sodium in treatment } \\
\text { of acute migraine } \\
\text { attacks } \\
\text { Naproxen sodium } \\
\text { dose was } 500 \mathrm{mg} \text { in } 3 \\
\text { trials; } 825 \mathrm{mg} \text { in one } \\
\text { trial }\end{array}$ & $\begin{array}{l}\text { Naproxen sodium was more effective than placebo: pooled risk ratios were } 1.58 \\
(95 \% \text { CI } 1.41-1.77, p<0.00001) \text {, and } 2.22 \text { ( } 95 \% \text { CI } 1.46-3.37, p=0.0002), \\
\text { respectively, for headache relief at } 2 \mathrm{~h} \text { and pain-free at } 2 \mathrm{~h} \\
\text { No significant difference in headache recurrence between naproxen sodium \& } \\
\text { placebo } \\
\text { Risk of any AE was greater with naproxen sodium than placebo (pooled risk ratio } \\
1.29,96 \% \text { CI } 1.04-1.60, p=0.02) ; \text { most common AEs with naproxen sodium were } \\
\text { nausea, dizziness, dyspepsia, abdominal pain }\end{array}$ & $\begin{array}{l}\text { Naproxen sodium is more effective but may cause more } \\
\text { adverse events than placebo in moderate to severe migraine; it } \\
\text { is effective in reducing headache intensity, rendering pain-free } \\
\text { at } 2 \mathrm{~h} \& \text { improving migraine-associated symptoms. } \\
\text { Limitations: one study had small number of patients; } \\
\text { inconsistencies in descriptions of outcomes adopted by } \\
\text { individual trials (but all trials were high quality) }\end{array}$ \\
\hline $\begin{array}{l}\text { ASA } \pm \text { antiemetic } \\
\left(\text { metoclopramide) }(2010)^{49}\right. \\
13 \text { RCTs } \\
\mathrm{n}=4222 \text { (treating } 5261 \\
\text { migraine headaches of } \\
\text { moderate to severe } \\
\text { intensity) }\end{array}$ & $\begin{array}{l}\text { To determine } \\
\text { efficacy \& } \\
\text { tolerability of ASA } \\
\text { ( } 900 \text { or } 1,000 \mathrm{mg}), \\
\text { alone or in } \\
\text { combination with } \\
\text { metoclopramide ( } 10 \\
\text { mg), compared to } \\
\text { placebo \& other } \\
\text { active comparators } \\
\text { (sumatriptan) in } \\
\text { treatment of acute } \\
\text { migraine headaches } \\
\text { in adults }\end{array}$ & $\begin{array}{l}\text { Primary efficacy outcomes: pain-free at } 2 \mathrm{~h} \text {, without use of rescue medications; } \\
\text { headache relief* at } 1 \mathrm{~h} \& 2 \mathrm{~h} \text {; sustained pain-free** over } 24 \mathrm{~h} \text {; sustained pain } \\
\text { reduction*** over } 24 \mathrm{~h} \\
\text { Main results: ASA } 900 \mathrm{mg} \text { or } 1,000 \mathrm{mg} \text { vs. placebo: } \\
\text { 2-h pain-free: } 24 \% \text { vs. } 11 \% \text { (NNT=8.1) 2-h headache relief: } 52 \% \text { vs. } 32 \% \\
\text { (NNT=4.9) } \\
\text { 24-h sustained headache relief: } 39 \% \text { vs. } 24 \% \text { (NNT=6.6) } \\
\text { ASA } 900 \mathrm{mg}+\text { metoclopramide } 10 \mathrm{mg} \text { vs. placebo: } \\
\text { 2-h pain-free: } 18 \% \text { vs. } 7 \% \text { (NNT=8.8) 2-h headache relief: } 57 \% \text { vs. } 26 \% \\
\text { (NNT=3.3) } \\
\text { 24-h sustained headache relief: } 37 \% \text { vs. } 17 \% \text { (NNT=6.2) } \\
\text { No data for } 24-\mathrm{h} \text { sustained pain-free } \\
\text { Sumatriptan } 50 \text { mg did not differ from ASA alone for 2-h pain-free and headache } \\
\text { relief, while sumatriptan } 100 \mathrm{mg} \text { was better than ASA + metoclopramide for 2-h } \\
\text { pain-free (but not headache relief); there was no data for } 24 \text {-h headache relief }\end{array}$ & $\begin{array}{l}\text { ASA } 1,000 \mathrm{mg} \text { is an effective treatment for acute migraine } \\
\text { headaches, similar to sumatriptan } 50 \text { or } 100 \mathrm{mg} \text {, with reductior } \\
\text { in both pain \& associated symptoms such as nausea \& } \\
\text { photophobia; addition of metoclopramide } 10 \mathrm{mg} \text { improves } \\
\text { relief of nausea \& vomiting; sumatriptan } 100 \mathrm{mg} \text { was superior } \\
\text { to ASA/metoclopramide for pain-free at } 2 \mathrm{~h} \text {. } \\
\text { AEs mainly mild \& transient, \& slightly more common with } \\
\text { ASA than placebo, but less common than with sumatriptan } 10 \\
\text { mg. } \\
\text { Further studies are needed to establish efficacy of ASA } \\
\text { compared to other triptans \& NSAIDs } \\
\text { Limitations: small number of actual events used to calculate } \\
\text { some results (e.g., small number of vomiting episodes) in } \\
\text { estimations of efficacy concerning relief of associated } \\
\text { symptoms }\end{array}$ \\
\hline
\end{tabular}


Table 7: Meta-analyses/systematic reviews of acetaminophen, ASA and NSAIDs for acute migraine treatment [part 2] continued

\begin{tabular}{|c|c|c|c|}
\hline & & $\begin{array}{l}\text { Associated symptoms (nausea, vomiting, photophobia \& phonophobia) were } \\
\text { reduced with ASA vs. placebo; addition of metoclopramide significantly reduced } \\
\text { nausea }(p<0.00006) \& \text { vomiting }(p=0.002) \text { vs. ASA alone } \\
\text { AEs mostly mild \& transient, occurring slightly more often with ASA vs. placebo }\end{array}$ & \\
\hline $\begin{array}{l}\text { ASA effervescent (eASA) } \\
(2007)^{50} \\
3 \text { single-dose RCTs } \\
\text { (individual patient data } \\
\text { meta-analysis) } \\
\text { e ASA: } n=392 ; \\
\text { sumatriptan } 50 \mathrm{mg}: \mathrm{n}=221 \text {; } \\
\text { placebo: } \mathrm{n}=378 \\
\text { Total of } 991 \text { attacks } \\
\text { Types of participants: } \\
\text { adults ( } \geq 18 \text { years); IHS } \\
\text { criteria for migraine } \\
\text { diagnosis; history of } \\
\text { migraine at least } 1 \text { year; } 1-6 \\
\text { attacks per month }\end{array}$ & $\begin{array}{l}\text { To evaluate efficacy } \\
\text { \& safety eASA } \\
1,000 \mathrm{mg} \text { in } \\
\text { comparison with } \\
\text { sumatriptan } 50 \mathrm{mg} \\
\text { \& placebo }\end{array}$ & $\begin{array}{l}\text { Pain (i.e., headache) relief at } 2 \text { h: eASA: } 51.5 \% \text { (95\% CI: } 46.6-56.5 \%) \\
\text { Sumatriptan: } 46.6 \% \text { (95\% CI: 40.0-53.2\%) Placebo: } 33.9 \% \text { (95\% CI: } 29.1- \\
38.6 \% \text { ) } \\
\text { Pain-free at } 2 \text { h: eASA: } 27.1 \%(95 \% \text { CI: } 22.6-31.4 \%) \\
\text { Sumatriptan: } 29 \% \text { (95\% CI: } 23.0-34.9 \%) \\
\text { Placebo: } 15.1 \% \text { (95\% CI: } 11.5-18.7 \%) \\
\text { Sustained pain-free up to } 24 \text { h: eASA: } 23.5 \% \text { (95\% CI: } 19-3-27.7 \%) \\
\text { Sumatriptan: } 22.2 \% \text { (95\% CI: } 17.7-27.6 \%) \\
\text { Placebo: } 14.6 \% \text { (95\% CI: } 11.0-18.1 \%) \\
\text { Lower frequency of AEs (including gastrointestinal) in eASA vs. sumatriptan } \\
\text { group (12.0\% vs. } 16.2 \%)\end{array}$ & $\begin{array}{l}\text { Effervescent ASA } 1,000 \mathrm{mg} \text { is as effective as sumatriptan } 50 \\
\text { mg for treatment of acute migraine attacks (including severe } \\
\text { attacks) \& has better side effect profile } \\
\text { Limitations: meta-analysis is based on single-dose studies, } \\
\text { which may have resulted in lower frequency of adverse events } \\
\text { for eASA vs. sumatriptan }\end{array}$ \\
\hline $\begin{array}{l}\text { Diclofenac potassium } \\
(2012)^{59} \\
5 \text { RCTs } \\
\mathrm{n}=1356 \\
\\
\text { Types of participants: } \\
\text { adults ( } \geq 18 \text { years); IHS } \\
\text { criteria for migraine } \\
\text { diagnosis; stable } \\
\text { prophylactic therapy } \\
\text { allowed }\end{array}$ & $\begin{array}{l}\text { To determine } \\
\text { efficacy \& } \\
\text { tolerability of } \\
\text { diclofenac alone or in } \\
\text { combination with an } \\
\text { antiemetic, compared } \\
\text { to placebo and other } \\
\text { active interventions } \\
\text { in treatment of acute } \\
\text { migraine headaches } \\
\text { in adults }\end{array}$ & $\begin{array}{l}\text { Primary efficacy outcomes: pain-free at } 1 \mathrm{~h} \& 2 \mathrm{~h} \text {, without use of rescue } \\
\text { medication; headache relief* at } 1 \mathrm{~h} \& 2 \mathrm{~h} \text {; sustained pain-free** during } 24 \mathrm{~h} \text { post- } \\
\text { dose (pain-free at } 2 \mathrm{~h} \& \text { no use of rescue medication or recurrence of moderate to } \\
\text { severe pain within } 24 \mathrm{~h} \text { ); sustained headache relief*** during } 24 \mathrm{~h} \text { post-dose } \\
\text { For single dose studies of diclofenac potassium vs. placebo ( } 2 \text { studies): } \\
\text { 2-h headache relief: } 55 \% \text { vs. } 39 \% \text { (NNT }=6.2) 2 \text {-h pain-free: } 22 \% \text { vs. } 11 \% \text { (NNT } \\
=8.9 \text { ) } \\
\text { Sustained pain-free }(24 \mathrm{~h} \text { ): } 19 \% \text { vs. } 8.2 \% \text { (NNT }=9.5 \text { ) } \\
\text { Comparison with sumatriptan } 100 \mathrm{mg} \text { oral: } \\
\text { Diclofenac potassium was more effective vs. placebo in reducing headache pain } \\
\text { at } 2 \mathrm{~h} \text { using VAS ( } p<0.001 ; 50 \mathrm{mg} \& 100 \mathrm{mg} \text { doses had similar efficacy); no } \\
\text { statistically significant difference between either dose of diclofenac potassium \& } \\
\text { sumatriptan } 100 \mathrm{mg} \text {. } \\
\text { AEs mostly mild to moderate and transient with diclofenac potassium; same rate } \\
\text { as placebo }\end{array}$ & $\begin{array}{l}\text { Oral diclofenac potassium } 50 \mathrm{mg} \text { is an effective treatment for } \\
\text { acute migraine, providing relief from pain and associated } \\
\text { symptoms; only a minority of patients achieved pain-free } \\
\text { responses. } \\
\text { AEs are mostly mild and transient (same rate as placebo); } \\
\text { further head-to-head studies with other acute treatments are } \\
\text { needed } \\
\text { Limitations: studies used different doses and formulations of } \\
\text { diclofenac, different dosing regimens (single dose or with } \\
\text { optional second dose) \& different levels of baseline pain; } \\
\text { insufficient data for analysis of } 100 \text { mg dose; single dose } \\
\text { studies may not reveal rare but potentially serious AEs }\end{array}$ \\
\hline
\end{tabular}

*Headache relief: pain reduced from moderate or severe to none or mild, without use of rescue medication. **Sustained pain-free over 24 h: painfree within $2 \mathrm{~h}$, with no use of rescue medication ore recurrence within $24 \mathrm{~h}$. $* * *$ Sustained pain reduction/headache relief over $24 \mathrm{~h}$ : headache relief at $2 \mathrm{~h}$, sustained for $24 \mathrm{~h}$, with no use of rescue medication or a second dose of study medication. RCTs = randomized, controlled trials; IHS = International Headache Society; NNT = number-needed-to treat; NNH = number-needed-to-harm; NS = non-statistically significant; AEs = adverse events; $\mathrm{CI}=$ confidence interval

using a higher dose of sumatriptan (e.g., $100 \mathrm{mg}$ ) would have provided additional benefit is unknown. ${ }^{80}$

\section{b) Domperidone}

There is some evidence for efficacy of domperidone combined with acetaminophen for acute migraine. ${ }^{81,82} \mathrm{~A}$ randomized, double-blind, crossover study compared the fixed combination (not available in Canada) of acetaminophen $500 \mathrm{mg}$ and domperidone $10 \mathrm{mg}$ with sumatriptan $50 \mathrm{mg} .{ }^{81}$ There was no significant difference in headache relief at $2 \mathrm{~h}$ between the two treatments (36.4\% vs. $33.3 \%$, respectively), and improvement in nausea was the same with both. However, fewer side effects were reported with the acetaminophen and domperidone combination. Domperidone has an advantage over metoclopramide in that it is not associated with extrapyramidal effects or tardive dyskinesia. However, it can cause QT prolongation, which may lead to serious ventricular arrhythmias and sudden cardiac death, especially in patients older than 60 years-of-age and with daily doses greater than $30 \mathrm{mg}$ (Health Canada Endorsed Important Safety Information on Domperidone Maleate, March 2, 2012).

\section{Recommendations (adjunctive drugs)}

1. Strong recommendation, moderate quality evidence: Metoclopramide (10 $\mathrm{mg}$ orally) is recommended for use with acute migraine medications for migraine attacks to improve relief of nausea.

2. Strong recommendation, low quality evidence: Domperidone (10 mg orally) is recommended for use with acute migraine medications for migraine attacks to improve relief of nausea.

\section{Conclusions}

In this targeted review, strong recommendations for use in acute migraine therapy have been made for 7 triptans, 4 NSAIDs (including ASA), and acetaminophen. All of these had high quality evidence supporting their use. Another medication, dihydroergotamine (intranasal or SC self-injection), received a weak recommendation for use related to the balance between efficacy and side effects, based on moderate quality evidence. Three other medications, all of which were not recommended for routine use, received weak recommendations for use: 
Table 8: Summary of Recommendations for Medications for Acute Migraine Treatment *

\begin{tabular}{|c|c|c|}
\hline Drug $\&$ route(s) & Recommendation & Quality of Evidence \\
\hline \multicolumn{3}{|l|}{ 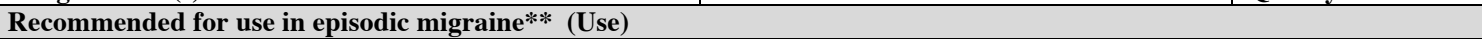 } \\
\hline \multicolumn{3}{|l|}{ Triptans and other migraine-specific medications: } \\
\hline Almotriptan (oral) & Strong & High \\
\hline Eletriptan (oral) & Strong & High \\
\hline Frovatriptan (oral) & Strong & High \\
\hline Naratriptan (oral) & Strong & High \\
\hline Rizatriptan (oral) & Strong & High \\
\hline Sumatriptan (SC, oral, intranasal) & Strong & High \\
\hline Zolmitriptan (oral, intranasal) & Strong & High \\
\hline Dihydroergotamine (intranasal, SC self-injection) & Weak & Moderate \\
\hline Ergotamine (oral) & Weak (not recommended for routine use) & Moderate \\
\hline \multicolumn{3}{|l|}{ ASA / NSAIDs: } \\
\hline ASA (oral) & Strong & High \\
\hline Diclofenac potassium (oral) & Strong & High \\
\hline Ibuprofen (oral) & Strong & High \\
\hline Naproxen sodium (oral) & Strong & High \\
\hline \multicolumn{3}{|l|}{ Other: } \\
\hline Acetaminophen (oral) & Strong & High \\
\hline \multicolumn{3}{|c|}{ Opioids and Tramadol (not recommended for routine use): } \\
\hline Opioid (i.e., codeine)- containing medications (oral) & Weak & Low \\
\hline Tramadol-containing medications (oral) & Weak & Moderate \\
\hline \multicolumn{3}{|l|}{ Anti-emetics: } \\
\hline Domperidone (oral) & Strong & Low \\
\hline Metoclopramide (oral) & Strong & Moderate \\
\hline \multicolumn{3}{|c|}{ Not recommended for use in episodic migraine ${ }^{* *}\left(\right.$ Do not use) ${ }^{* * *}$} \\
\hline Butalbital-containing medications (oral) & Strong & Low \\
\hline Butorphanol (intranasal) & Strong & Low \\
\hline
\end{tabular}

ergotamine, codeine-containing combination analgesics, and tramadol-containing analgesics. Supporting evidence for use for these three medications ranged from low to moderate quality evidence.

Two anti-emetics, metoclopramide and domperidone, received strong recommendations for use, with moderate quality evidence for metoclopramide and low quality evidence for domperidone.

Two medications received strong "do not use" recommendation (except for use in exceptional circumstances): butalbital-containing medications and butorphanol (intranasal), supported by low quality evidence. The above recommendations are summarized in Table 8.

Choice of an acute medication for a specific patient must be individualized, based on evidence for efficacy, potential drug side effects, co-existent medical and psychiatric illnesses, and patient preference. It also needs to be recognized that patient response to acute migraine medications is idiosyncratic and often cannot be predicted in advance. Therefore, multiple treatment options may need to be tried before an excellent medication for the patient is found.

Patient preference may also include considerations of cost, and cost may be a societal consideration as well. However, it must be kept in mind that most of the costs associated with migraine are indirect costs related to missed work and other activities, and these are often much larger than the direct costs which include medication costs.

The principles of acute migraine therapy are discussed further in Section 1 of this guideline, and acute medication choice for individual patients is discussed in greater detail in Section 3.

\section{REFERENCES}

1. Pryse-Phillips WE, Dodick DW, Edmeads JG, et al. Guidelines for the diagnosis and management of migraine in clinical practice. Canadian Headache Society.[see comment][erratum appears in CMAJ 1997 Nov 15;157(10):1354]. [Review] [160 refs]. CMAJ. 1997; 156:1273-87.

2. Lipton RB, Stewart WF. Acute migraine therapy: do doctors understand what patients with migraine want from therapy? Headache. 1999;39:S20-6.

3. Guyatt GH, Oxman AD, Vist GE, et al. GRADE: an emerging consensus on rating quality of evidence and strength of recommendations. BMJ. 2008;336:924-6.

4. Guyatt GH, Oxman AD, Kunz R, et al. What is "quality of evidence" and why is it important to clinicians? BMJ. 2008; 336:995-8.

5. Balshem H, Helfand M, Schunemann HJ, et al. GRADE guidelines: 3. Rating the quality of evidence. J Clin Epidemiol. 2011;64: 401-6. 
6. Cuello Garcia CA, Pacheco Alvarado KP, Perez Gaxiola G. Grading recommendations in clinical practice guidelines: randomised experimental evaluation of four different systems. Arch Dis Child. 2011;96:723-8.

7. Brozek JL, Akl EA, Compalati E, et al. Grading quality of evidence and strength of recommendations in clinical practice guidelines part 3 of 3 . The GRADE approach to developing recommendations. Allergy. 2011;66:588-95.

8. Oldman AD, Smith LA, McQuay HJ, Moore RA. Pharmacological treatments for acute migraine: quantitative systematic review. Pain. 2002;97:247-57.

9. Johnston MM, Rapoport AM. Triptans for the management of migraine. Drugs. 2010;70:1505-18.

10. Dodick D, Lipton RB, Martin V, et al. Consensus statement: cardiovascular safety profile of triptans (5-HT agonists) in the acute treatment of migraine. [Review] [66 refs]. Headache. 2004; 44:414-25.

11. Tepper SJ, Millson D. Safety profile of the triptans. [Review] [51 refs]. Expert Opin Drug Saf. 2003;2:123-32.

12. Wenzel RG, Tepper S, Korab WE, Freitag F. Serotonin syndrome risks when combining SSRI/SNRI drugs and triptans: is the FDA's alert warranted? Ann Pharmacother. 2008;42:1692-6.

13. Gillman PK. Triptans, serotonin agonists, and serotonin syndrome (serotonin toxicity): a review. Headache. 2010;50:264-72.

14. Ferrari MD, Goadsby PJ, Roon KI, Lipton RB. Triptans (serotonin, 5-HT1B/1D agonists) in migraine: detailed results and methods of a meta-analysis of 53 trials. [see comment][erratum appears in Cephalalgia. $2003 \mathrm{Feb}$;23(1):71.]. Cephalalgia. 2002;22:633-58.

15. Ferrari MD, Roon KI, Lipton RB, Goadsby PJ. Oral triptans (serotonin 5-HT(1B/1D) agonists) in acute migraine treatment: a meta-analysis of 53 trials. [see comment]. Lancet. 2001;358: 1668-75.

16. Pascual J, Mateos V, Roig C, Sanchez-Del-Rio M, Jimenez D. Marketed oral triptans in the acute treatment of migraine: a systematic review on efficacy and tolerability. Headache. 2007;47:1152-68.

17. Gawel MJ, Worthington I, Maggisano A. A systematic review of the use of triptans in acute migraine. [see comment]. [Review] [74 refs]. Can J Neurol Sci. 2001;28:30-41.

18. Lipton RB, Bigal ME, Goadsby PJ. Double-blind clinical trials of oral triptans vs other classes of acute migraine medication - a review. [Review] [35 refs]. Cephalalgia. 2004;24:321-32.

19. Smith TR, Sunshine A, Stark SR, Littlefield DE, Spruill SE, Alexander WJ. Sumatriptan and naproxen sodium for the acute treatment of migraine. Headache. 2005;45:983-91.

20. Brandes JL, Kudrow D, Stark SR, et al. Sumatriptan-naproxen for acute treatment of migraine: a randomized trial. JAMA. 2007; 297:1443-54

21. Mathew NT, Landy S, Stark S, et al. Fixed-dose sumatriptan and naproxen in poor responders to triptans with a short half-life. Headache. 2009;49:971-82

22. Vollono C, Capuano A, Mei D, et al. Multiple attack study on the available triptans in Italy versus placebo. Eur J Neurol. 2005; 12:557-63.

23. Dodick DW. Triptan nonresponder studies: implications for clinical practice. Headache. 2005;45:156-62.

24. Diener HC, Gendolla A, Gebert I, Beneke M. Almotriptan in migraine patients who respond poorly to oral sumatriptan: a double-blind, randomized trial. Eur Neurol. 2005;53:41-8.

25. Farkkila M, Olesen J, Dahlof C, et al. Eletriptan for the treatment of migraine in patients with previous poor response or tolerance to oral sumatriptan. Cephalalgia. 2003;23:463-71.

26. Stark S, Spierings EL, McNeal S, Putnam GP, Bolden-Watson CP, O'Quinn S. Naratriptan efficacy in migraineurs who respond poorly to oral sumatriptan. Headache. 2000;40:513-20.

27. Klapper J, Lucas C, Rosjo O, Charlesworth B, ZODIAC study g. Benefits of treating highly disabled migraine patients with zolmitriptan while pain is mild. [see comment]. Cephalalgia. 2004;24:918-24.

28. Cady R, Elkind A, Goldstein J, Keywood C. Randomized, placebocontrolled comparison of early use of frovatriptan in a migraine attack versus dosing after the headache has become moderate or severe. Curr Med Res Opin. 2004;20:1465-72.
29. Brandes JL, Kudrow D, Cady R, Tiseo PJ, Sun W, Sikes CR. Eletriptan in the early treatment of acute migraine: influence of pain intensity and time of dosing. Cephalalgia. 2005;25:735-42.

30. Barbanti P, Carpay JA, Kwong WJ, Ahmad F, Boswell D. Effects of a fast disintegrating/rapid release oral formulation of sumatriptan on functional ability in patients with migraine. Curr Med Res Opin. 2004;20:2021-9.

31. Jelinski SE, Becker WJ, Christie SN, Ahmad FE, Pryse-Phillips W, Simpson SD. Pain free efficacy of sumatriptan in the early treatment of migraine. Can J Neur Sci. 2006;33:73-9.

32. Cady R, Martin V, Mauskop A, et al. Efficacy of Rizatriptan $10 \mathrm{mg}$ administered early in a migraine attack. Headache. 2006;46: 914-24.

33. Winner P, Mannix LK, Putnam DG, et al. Pain-free results with sumatriptan taken at the first sign of migraine pain: 2 randomized, double-blind, placebo-controlled studies. Mayo Clin Proc. 2003;78:1214-22.

34. Loder E. Triptan therapy in migraine. N Engl J Med. 2010;363: 63-70.

35. Geraud G, Keywood C, Senard JM. Migraine headache recurrence: relationship to clinical, pharmacological, and pharmacokinetic properties of triptans. Headache. 2003;43:376-88.

36. Tfelt-Hansen P, Saxena PR, Dahlof C, et al. Ergotamine in the acute treatment of migraine: a review and European consensus. [Review] [84 refs]. Brain. 2000;123:9-18.

37. Anonymous Efficacy, safety, and tolerability of dihydroergotamine nasal spray as monotherapy in the treatment of acute migraine. Dihydroergotamine Nasal Spray Multicenter Investigators. Headache. 1995;35:177-84.

38. Treves TA, Kuritzky A, Hering R, Korczyn AD. Dihydroergotamine nasal spray in the treatment of acute migraine. Headache. 1998; 38:614-7.

39. Boureau F, Kappos L, Schoenen J, Esperanca P, Ashford E. A clinical comparison of sumatriptan nasal spray and dihydroergotamine nasal spray in the acute treatment of migraine. Int J Clin Pract. 2000;54:281-6.

40. Touchon J, Bertin L, Pilgrim AJ, Ashford E, Bes A. A comparison of subcutaneous sumatriptan and dihydroergotamine nasal spray in the acute treatment of migraine. Neurology. 1996;47:361-5.

41. Winner P, Ricalde O, Le Force B, Saper J, Margul B. A double-blind study of subcutaneous dihydroergotamine vs subcutaneous sumatriptan in the treatment of acute migraine. [see comment]. Arch Neurol. 1996;53:180-4

42. Anonymous. A randomized, double-blind comparison of sumatriptan and Cafergot in the acute treatment of migraine. The Multinational Oral Sumatriptan and Cafergot Comparative Study Group. Eur Neurol. 1991;31:314-22.

43. Diener HC, Jansen JP, Reches A, et al. Efficacy, tolerability and safety of oral eletriptan and ergotamine plus caffeine (Cafergot) in the acute treatment of migraine: a multicentre, randomised, double-blind, placebo-controlled comparison. Eur Neurol. 2002; 47:99-107.

44. Dowson AJ, Massiou H, Lainez JM, Cabarrocas X. Almotriptan is an effective and well-tolerated treatment for migraine pain: results of a randomized, double-blind, placebo-controlled clinical trial. Cephalalgia. 2002;22:453-61.

45. Derry CJ, Derry S, Moore RA. Sumatriptan (oral route of administration) for acute migraine attacks in adults. Cochrane Database of Systematic Reviews. 2012;2:008615.

46. Wenzel RG, Sarvis CA, Krause ML. Over-the-counter drugs for acute migraine attacks: literature review and recommendations. Pharmacotherapy. 2003;23:494-505.

47. Silberstein S, Tepper S, Brandes J, et al. Randomized, placebocontrolled trial of rofecoxib in the acute treatment of migraine. Neurology. 2004;62:1552-7.

48. Misra UK, Jose M, Kalita J. Rofecoxib versus ibuprofen for acute treatment of migraine: a randomised placebo controlled trial. Postgrad Med J. 2004;80:720-3.

49. Kirthi V, Derry S, Moore RA, McQuay HJ. Aspirin with or without an antiemetic for acute migraine headaches in adults. Cochrane Database Syst Rev. 2010;4:008041. 
50. Lampl C, Voelker M, Diener HC. Efficacy and safety of 1,000 mg effervescent aspirin: individual patient data meta-analysis of three trials in migraine headache and migraine accompanying symptoms. J Neurol. 2007;254:705-12.

51. Suthisisang C, Poolsup N, Kittikulsuth W, Pudchakan P, Wiwatpanich P. Efficacy of low-dose ibuprofen in acute migraine treatment: systematic review and meta-analysis. Ann Pharmacother. 2007;41:1782-91.

52. Rabbie R, Derry S, Moore RA, McQuay HJ. Ibuprofen with or without an antiemetic for acute migraine headaches in adults. Cochrane Database Syst Rev. 2010;008039.

53. Kellstein DE, Lipton RB, Geetha R, et al. Evaluation of a novel solubilized formulation of ibuprofen in the treatment of migraine headache: a randomized, double-blind, placebo-controlled, doseranging study. Cephalalgia. 2000;20:233-43.

54. Misra UK, Kalita J, Yadav RK. Rizatriptan vs. ibuprofen in migraine: a randomised placebo-controlled trial. J Headache Pain. 2007;8:175-9.

55. Suthisisang C, Poolsup N, Suksomboon N, Lertpipopmetha V, Tepwitukgid B. Meta-analysis of the efficacy and safety of naproxen sodium in the acute treatment of migraine. Headache. 2010;50:808-18.

56. McNeely W, Goa KL. Diclofenac-potassium in migraine: a review. Drugs. 1999;57:991-1003.

57. Diener HC, Montagna P, Gacs G, et al. Efficacy and tolerability of diclofenac potassium sachets in migraine: a randomized, doubleblind, cross-over study in comparison with diclofenac potassium tablets and placebo. Cephalalgia. 2006;26:537-47.

58. Lipton RB, Grosberg B, Singer RP, et al. Efficacy and tolerability of a new powdered formulation of diclofenac potassium for oral solution for the acute treatment of migraine: results from the International Migraine Pain Assessment Clinical Trial (IMPACT). Cephalalgia. 2010;30:1336-45.

59. Derry S, Rabbie R, Moore RA. Diclofenac with or without an antiemetic for acute migraine headaches in adults. Cochrane Database Syst Rev. 2012;2:008783.

60. Anonymous Acute treatment of migraine attacks: efficacy and safety of a nonsteroidal anti-inflammatory drug, diclofenacpotassium, in comparison to oral sumatriptan and placebo. The Diclofenac-K/Sumatriptan Migraine Study Group. Cephalalgia. 1999; 19:232-40

61. Diener HC, Montagna P, Gacs G, et al. Efficacy and tolerability of diclofenac potassium sachets in migraine: a randomized, doubleblind, cross-over study in comparison with diclofenac potassium tablets and placebo. Cephalalgia. 2006;26:537-47.

62. Lipton RB, Baggish JS, Stewart WF, Codispoti JR, Fu M. Efficacy and safety of acetaminophen in the treatment of migraine: results of a randomized, double-blind, placebo-controlled, populationbased study. Arch Intern Med. 2000;160:3486-92.

63. Prior MJ, Codispoti JR, Fu M. A randomized, placebo-controlled trial of acetaminophen for treatment of migraine headache. Headache. 2010;50:819-33.

64. Derry S, Moore RA, McQuay HJ. Paracetamol (acetaminophen) with or without an antiemetic for acute migraine headaches in adults. Cochrane Database of Systematic Reviews 2010;008040.

65. Silberstein SD, McCrory DC. Butalbital in the treatment of headache: history, pharmacology, and efficacy. [Review] [44 refs]. Headache. 2001;41:953-67.

66. Boureau F, Joubert JM, Lasserre V, Prum B, Delecoeuillerie G. Double-blind comparison of an acetaminophen $400 \mathrm{mg}$-codeine $25 \mathrm{mg}$ combination versus aspirin $1000 \mathrm{mg}$ and placebo in acute migraine attack. Cephalalgia. 1994;14:156-61.

67. Loder E. Post-marketing experience with an opioid nasal spray for migraine: lessons for the future. Cephalalgia. 2006;26:89-97.

68. Hoffert MJ, Couch JR, Diamond S, et al. Transnasal butorphanol in the treatment of acute migraine. Headache. 1995;35:65-9.

69. Goldstein J, Gawel MJ, Winner P, et al. Comparison of butorphanol nasal spray and fiorinal with codeine in the treatment of migraine. Headache. 1998;38:516-22.

70. Senay EC, Adams EH, Geller A, et al. Physical dependence on Ultram (tramadol hydrochloride): both opioid-like and atypical withdrawal symptoms occur. Drug Alcohol Depend. 2003;69: $233-41$
71. Raffa RB. Basic pharmacology relevant to drug abuse assessment: tramadol as example. J Clin Pharm Ther. 2008;33:101-8.

72. Tjaderborn M, Jonsson AK, Ahlner J, Hagg S. Tramadol dependence: a survey of spontaneously reported cases in Sweden. Pharmacoepidemiol Drug Saf. 2009;18:1192-8.

73. Silberstein SD, Freitag FG, Rozen TD, et al. Tramadol/ acetaminophen for the treatment of acute migraine pain: findings of a randomized, placebo-controlled trial. Headache. 2005;45: 1317-27.

74. Wenzel RG, Sarvis CA. Do butalbital-containing products have a role in the management of migraine? [Review] [55 refs]. Pharmacotherapy. 2002;22:1029-35.

75. Raja M, Altavista MC, Azzoni A, Albanese A. Severe barbiturate withdrawal syndrome in migrainous patients. Headache. 1996; 36:119-21.

76. Derosier F, Sheftell F, Silberstein S, et al. Sumatriptan-naproxen and butalbital: A double-blind, placebo-controlled crossover study. Headache. 2012;52:530-43.

77. Geraud G, Compagnon A, Rossi A, COZAM Study G. Zolmitriptan versus a combination of acetylsalicylic acid and metoclopramide in the acute oral treatment of migraine: a double-blind, randomised, three-attack study. Eur Neurol. 2002;47:88-98.

78. Chabriat H, Joire JE, Danchot J, Grippon P, Bousser MG. Combined oral lysine acetylsalicylate and metoclopramide in the acute treatment of migraine: a multicentre double-blind placebocontrolled study. Cephalalgia. 1994;14:297-300.

79. Tfelt-Hansen P, Henry P, Mulder LJ, Scheldewaert RG, Schoenen J, Chazot G. The effectiveness of combined oral lysine acetylsalicylate and metoclopramide compared with oral sumatriptan for migraine. [see comment]. Lancet. 1995;346: 923-6.

80. Schulman EA, Dermott KF. Sumatriptan plus metoclopramide in triptan-nonresponsive migraineurs. [see comment]. Headache. 2003;43:729-33.

81. Dowson A, Ball K, Haworth D. Comparison of a fixed combination of domperidone and paracetamol (Domperamol) with sumatriptan $50 \mathrm{mg}$ in moderate to severe migraine: a randomised UK primary care study. Curr Med Res Opin. 2000;16:190-7.

82. MacGregor EA, Wilkinson M, Bancroft K. Domperidone plus paracetamol in the treatment of migraine. Cephalalgia. 1993;13: 124-7.

83. Derry CJ, Derry S, Moore RA. Sumatriptan (subcutaneous route of administration) for acute migraine attacks in adults. Cochrane Database Syst Rev. 2012;2:009665.

84. Derry CJ, Derry S, Moore RA. Sumatriptan (intranasal route of administration) for acute migraine attacks in adults. Cochrane Database Syst Rev. 2012;2:009663.

85. Chen LC, Ashcroft DM. Meta-analysis of the efficacy and safety of zolmitriptan in the acute treatment of migraine. Headache. 2008; 48:236-47.

86. Ashcroft DM, Millson D. Naratriptan for the treatment of acute migraine: meta-analysis of randomised controlled trials. Pharmacoepidemiol Drug Saf. 2004;13:73-82.

87. Poolsup N, Leelasangaluk V, Jittangtrong J, Rithlamlert C, Ratanapantamanee N, Khanthong M. Efficacy and tolerability of frovatriptan in acute migraine treatment: systematic review of randomized controlled trials. J Clin Pharm Ther. 2005;30: 521-32.

88. Chen LC, Ashcroft DM. Meta-analysis examining the efficacy and safety of almotriptan in the acute treatment of migraine. Headache. 2007;47:1169-77.

89. Gallagher RM, Dennish G, Spierings EL, Chitra R. A comparative trial of zolmitriptan and sumatriptan for the acute oral treatment of migraine. [see comment]. Headache. 2000;40:119-28.

90. Gruffyd-Jones K, Kies B, Middleton A, Mulder LJ, Rosjo O, Millson DS. Zolmitriptan versus sumatriptan for the acute oral treatment of migraine: a randomized, double-blind, international study. Eur J Neurol. 2001;8:237-45.

91. Bomhof M, Paz J, Legg N, Allen C, Vandormael K, Patel K. Comparison of rizatriptan $10 \mathrm{mg}$ vs. naratriptan $2.5 \mathrm{mg}$ in migraine. Eur Neurol. 1999;42:173-9. 
92. Visser WH, Terwindt GM, Reines SA, Jiang K, Lines CR, Ferrari MD. Rizatriptan vs sumatriptan in the acute treatment of migraine. A placebo-controlled, dose-ranging study. Dutch/US Rizatriptan Study Group. Arch Neurol. 1996;53:1132-7.

93. Goldstein J, Ryan R, Jiang K, et al. Crossover comparison of rizatriptan $5 \mathrm{mg}$ and $10 \mathrm{mg}$ versus sumatriptan $25 \mathrm{mg}$ and $50 \mathrm{mg}$ in migraine. Rizatriptan Protocol 046 Study Group.[see comment]. Headache. 1998;38:737-47.

94. Tfelt-Hansen P, Teall J, Rodriguez F, et al. Oral rizatriptan versus oral sumatriptan: a direct comparative study in the acute treatment of migraine. Rizatriptan 030 Study Group. [see comment]. Headache. 1998;38:748-55.

95. Kolodny A, Polis A, Battisti WP, Johnson-Pratt L, Skobieranda F, Rizatriptan Protocol 052 Study G. Comparison of rizatriptan 5 $\mathrm{mg}$ and $10 \mathrm{mg}$ tablets and sumatriptan $25 \mathrm{mg}$ and $50 \mathrm{mg}$ tablets. Cephalalgia. 2004;24:540-6.

96. Spierings EL, Gomez-Mancilla B, Grosz DE, Rowland CR, Whaley FS, Jirgens KJ. Oral almotriptan vs. oral sumatriptan in the abortive treatment of migraine: a double-blind, randomized, parallel-group, optimum-dose comparison. Arch Neurol 2001; 58:944-50.

97. Mathew NT, Schoenen J, Winner P, Muirhead N, Sikes CR. Comparative efficacy of eletriptan $40 \mathrm{mg}$ versus sumatriptan 100 mg. [see comment]. Headache. 2003;43:214-22.

98. Sandrini G, Farkkila M, Burgess G, Forster E, Haughie S, Eletriptan Steering C. Eletriptan vs sumatriptan: a double-blind, placebocontrolled, multiple migraine attack study. [see comment]. Neurology. 2002;59:1210-7.

99. Goadsby PJ, Massiou H, Pascual J, et al. Almotriptan and zolmitriptan in the acute treatment of migraine. Acta Neurol Scand. 2007; 115:34-40.

100. Steiner TJ, Diener HC, MacGregor EA, Schoenen J, Muirheads N, Sikes CR. Comparative efficacy of eletriptan and zolmitriptan in the acute treatment of migraine. Cephalalgia. 2003;23:942-52.
101. Savi L, Omboni S, Lisotto C, et al. A double-blind, randomized, multicenter, Italian study of frovatriptan versus rizatriptan for the acute treatment of migraine. J Headache Pain. 2011;12:219-26.

102. Tullo V, Allais G, Ferrari MD, et al. Frovatriptan versus zolmitriptan for the acute treatment of migraine: a double-blind, randomized, multicenter, Italian study. Neurol Sci. 2010;31: S51-4.

103. Bartolini M, Giamberardino MA, Lisotto C, et al. A double-blind, randomized, multicenter, Italian study of frovatriptan versus almotriptan for the acute treatment of migraine. J Headache Pain. 2011;12:361-8.

104. Myllyla VV, Havanka H, Herrala L, et al. Tolfenamic acid rapid release versus sumatriptan in the acute treatment of migraine: comparable effect in a double-blind, randomized, controlled, parallel-group study. Headache. 1998;38:201-7.

105. Anonymous Acute treatment of migraine attacks: efficacy and safety of a nonsteroidal anti-inflammatory drug, diclofenacpotassium, in comparison to oral sumatriptan and placebo. The Diclofenac-K/Sumatriptan Migraine Study Group. Cephalalgia. 1999;19:232-40

106. Anonymous A study to compare oral sumatriptan with oral aspirin plus oral metoclopramide in the acute treatment of migraine. The Oral Sumatriptan and Aspirin plus Metoclopramide Comparative Study Group. Eur Neurol. 1992;32:177-84.

107. Diener HC, Bussone G, de Liano H, et al. Placebo-controlled comparison of effervescent acetylsalicylic acid, sumatriptan and ibuprofen in the treatment of migraine attacks. Cephalalgia. 2004;24:947-54.

108. Goldstein J, Silberstein SD, Saper JR, et al. Acetaminophen, aspirin, and caffeine versus sumatriptan succinate in the early treatment of migraine: results from the ASSET trial. Headache. 2005;45:973-82. 